University of Florida Levin College of Law

UF Law Scholarship Repository

UF Law Faculty Publications

Faculty Scholarship

Winter 2015

\title{
Preventing Balkanization or Facilitating Racial Domination: A Critique of the New Equal Protection
}

Darren Lenard Hutchinson

University of Florida Levin College of Law, hutchinson@law.ufl.edu

Follow this and additional works at: https://scholarship.law.ufl.edu/facultypub

Part of the Civil Rights and Discrimination Commons, and the Constitutional Law Commons

\section{Recommended Citation}

Darren Lenard Hutchinson, Preventing Balkanization or Facilitating Racial Domination: A Critique of the New Equal Protection, 22 Va. J. Soc. Pol'y \& L. 1 (2015), available at available at http://scholarship.law.ufl.edu/facultypub/665

This Article is brought to you for free and open access by the Faculty Scholarship at UF Law Scholarship Repository. It has been accepted for inclusion in UF Law Faculty Publications by an authorized administrator of UF Law Scholarship Repository. For more information, please contact kaleita@law.ufl.edu. 


\section{PREVENTING BALKANIZATION OR FACILITATING RACIAL DOMINATION: A CRITIQUE OF THE NEW EQUAL PROTECTION}

\section{Darren Lenard Hutchinson*}

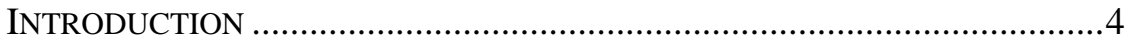

I. BALKANIZATION AND EQUAL PROTECTION .................................12

A. Balkanization: The Empirical Claim ........................................12

1. Colorblindness, Affirmative Action, and Balkanization .....12

2. Discriminatory Intent Rule................................................15

3. The End of Suspect Classes ...............................................16

a. Failure to Recognize New Suspect Classes ....................16

b. Class-to-Classification Shift ......................................19

B. Dignity and the Supreme Court .................................................20

1. Historical Usage of "Dignity" in Supreme Court

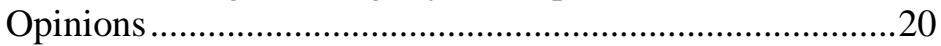

2. Contemporary Dignity Cases and Academic Reaction .......21

C. Dignity, Equality, and Pluralism Anxiety .................................22

1. Social Science and Pluralism Anxiety................................23

2. Social Capital and Dignity Theorists ..................................25

II. EQUAL PROTECTION, DigNiTY, AND GROUPS .................................25

A. Social Capital Literature Does Not Justify a New Equal

Protection ...................................................................26

1. Robert Putnam Does Not Believe His Scholarship Justifies Opposition to Group-Based Egalitarian Policies ..26

2. Putnam Has Retreated Somewhat from His Earlier Positions Regarding the Decline in Social Capital .............28

B. Social Capital Scholarship Has Received an Abundance of Academic Criticism ................................................................29

1. Causation Versus Correlation ...............................................30

2. Outmoded Measures of Civic Participation .........................31

3. Ignoring Racial and Class Inequality ...................................33

4. Negative Implications of Social Capital .............................36

\footnotetext{
* Stephen C. O’Connell Chair \& Professor of Law, University of Florida Levin College of Law. This Article has developed in various stages, and, along the way, I have received feedback from numerous individuals. I have presented earlier versions of this work at the Yale Critical Race Theory Conference, Washington University Law School, American University Washington College of Law, University of Florida Levin College of Law, University of CaliforniaDavis Law School, Santa Clara University Law School, the 2014 Mid-Atlantic People of Color Legal Scholarship Conference, and CUNY Law School. I thank Carlton Mark Waterhouse, Terry Smith, Nancy Marcus, Kimberly Norwood, Susan Carle, Ruthann Robson, Nancy Polikoff and numerous other participants at various workshops. I also thank my Research Assistant Spencer Winepol. Finally, I thank Dean Robert Jerry of the University of Florida for the generous research budget that allowed me to complete this project.
} 
III. PREVENTING BALKANIZATION OR FACILITATING RACIAL DOMINATION?

A. Social Psychology Theories of Group Behavior .........................40

1. Individualism Is a Social Construct ....................................41

2. Social Dominance Theory................................................41

B. Social Psychology Theory and Race Relations ........................43

1. Multiculturalism Versus Colorblindness .............................43

2. Groups Versus Individuals ................................................45

3. Contemporary Relevance of Racism...................................45

4. Whites Are a Vulnerable Social Group ................................47

C. The Supreme Court's Equal Protection Doctrine Mirrors White Viewpoints Regarding Race ..........................................48

1. Multiculturalism Versus Colorblindness ............................49

2. Groups Versus Individuals ..............................................49

3. Contemporary Relevance of Racism.................................49

4. Whites Are a Vulnerable Social Group ................................53

IV. TOWARDS A "NEWER" Equal PROTECTION That PROTECTS

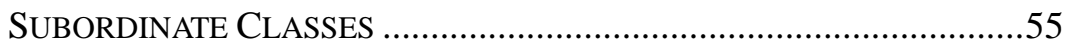

A. Groups, Difference, and Society ...............................................55

1. Healthy Responses to Anxiety ..........................................56

2. Multiculturalism Helps Society; Colorblindness Harms

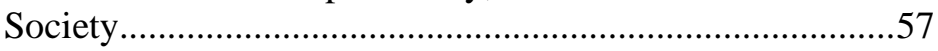

3. Group-Based Societies and Rights...................................60

4. Racism Is Still Relevant...................................................63

5. Whites Are Not Racially Oppressed ..................................64

B. Towards an Equal Protection Doctrine That Actually

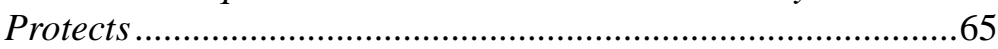

1. What Is Antisubordination Theory? .....................................65

2. A Few Thoughts About Dignity ………................................66

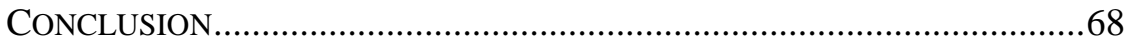




\section{PREVENTING BALKANIZATION OR \\ FACILITATING RACIAL DOMINATION: A CRITIQUE OF THE NEW EQUAL PROTECTION}

Darren Lenard Hutchinson

The Supreme Court requires that equal protection plaintiffs prove defendants acted with discriminatory intent. The intent rule has insulated from judicial invalidation numerous policies that harmfully impact racial and ethnic minorities. Court doctrine also mandates that state actors generally remain colorblind. The colorblindness doctrine has led to the judicial invalidation of policies designed to ameliorate the conditions of racial inequality. Taken together, these two equality doctrines facilitate racial domination. The Court justifies this outcome on the ground that the Constitution does not protect "group rights."

Constitutional law theorists have criticized these aspects of equal protection doctrine. Recently, however, some theorists have defended the Court's discarding of group-based equal protection. They argue that social justice advocates should pursue redress for vulnerable groups by asserting dignity-based liberty claims under the Due Process Clause. In a widely cited article, Professor Kenji Yoshino argues, in fact, that dignity is the "New Equal Protection." Applying insights from "social capital theory," Yoshino contends that group-based equal protection causes "pluralism anxiety"-or a fear of "balkanization" among the justices. Dignity arguments, by contrast, do not present such concerns because they rest on appeals to universal justice.

This Article contests the view that the Court should discontinue class-based equal protection in order to maintain social cohesion. Leading social capital theorists find that multiculturalism, though temporarily divisive (if at all), provides many long-term benefits. Also, numerous social psychology studies find that racial and ethnic inequality cause far more social disruption than group-based identities. This empirical research also demonstrates that the Court's equality doctrine mirrors the views regarding race relations held by most whites, while contradicting the perspectives of most persons of color. The enforcement of white majoritarian viewpoints should not serve as the foundation for an equality doctrine. Antisubordination theory, by contrast, would provide more egalitarian outcomes and should inform Court doctrine. 


\section{INTRODUCTION}

$\mathrm{T}$

HE Supreme Court's equal protection doctrine is in a state of disarray. Critics have condemned the Court for applying counterintuitive and ahistorical doctrines. ${ }^{1}$ Some of the harshest critics argue that the Court has inverted the meaning of equal protection such that it no longer protects vulnerable classes. ${ }^{2}$ Others contend that the Court extends protection primarily to advantaged groups. ${ }^{3}$ In addition, some scholars describe the current equal protection doctrine as undertheorized. ${ }^{4}$

Recently, some scholars have tried to place the Court's seemingly problematic rulings within a broader doctrinal and social context. Specifically, these scholars contend that the Supreme Court is uncomfortable with the traditional suspect class analysis. ${ }^{5}$ The Court believes that

\footnotetext{
${ }^{1}$ See Julie A. Nice, Equal Protection's Antinomies and the Promise of a CoConstitutive Approach, 85 CORNELL L. REV. 1392 (2000) (criticizing the "class to classification" shift in equal protection doctrine); Stephen A. Siegel, The Federal Government's Power to Enact Color-Conscious Laws: An Originalist Inquiry, 92 Nw. U. L. REV. 477 (1998) (arguing that application of strict colorblindness doctrine to federal legislation does not comport with historical meaning of equal protection).

2 See Reva B. Siegel, Why Equal Protection No Longer Protects: The Evolving Forms of Status-Enforcing State Action, 49 STAN. L. REV. 1111 (1997) [hereinafter R. Siegel, Why Equal Protection No Longer Protects] (arguing that equal protection doctrine functions as a preserver of social privilege and subordination).

${ }^{3}$ See Darren Lenard Hutchinson, "Unexplainable on Grounds Other than Race": The Inversion of Privilege and Subordination in Equal Protection Jurisprudence, 2003 U. ILL. L. REV. 615, 637-81 (2003) [hereinafter Hutchinson, Inversion of Privilege and Subordination]. See also R. Siegel, Why Equal Protection No Longer Protects, supra note 2, at 1114-46 (contending that Equal Protection privileges reinforce existing sexual and racial hierarchies).

${ }^{4}$ See Susannah W. Pollvogt, Windsor, Animus, and the Future of Marriage Equality, 113 COLUM. L. REV. SiDEBAR 204 (2013) (discussing uncertainty caused by the Court's use of "animus" in equal protection"); Jane S. Schacter, Ely at the Altar: Political Process Theory Through the Lens of the Marriage Debate, 109 MicH. L. REV. 1363, 1376 (2011) (arguing that the Court's equal protection cases "simply contain very little by way of exposition.").

${ }^{5}$ See, e.g., Reva B. Siegel, From Colorblindness to Antibalkanization: An Emerging Ground of Decision in Race Equality Cases, 120 YALE L.J. 1278 (2011) [hereinafter R. Siegel, From Colorblindness to Antibalkanization]; Neil S. Siegel, Race-Conscious Student Assignment Plans: Balkanization, Integration, and Individualized Consideration, 56 DUKE L.J. 781 (2006) [hereinafter S. Siegel, Race-Conscious Student Assignment Plans]; Kenji Yoshino, The New Equal Protection, 124 HARV. L. REV. 747 (2011) [hereinafter Yoshino, The New Equal Protection].
} 
group-based equal protection leads to balkanization. ${ }^{6}$ If society splinters into numerous groups, then this will diminish social cohesion. ${ }^{7}$

Although the Court has stopped using group-based equal protection, it has occasionally provided redress to vulnerable classes who have framed their claims as deprivations of due process. ${ }^{8}$ These contemporary due process rulings invalidate state action that deprives individuals of "dignity." 9 Unlike the suspect class doctrine, the dignity cases do not rest explicitly on the assertion that certain groups require more rigorous protection by the Court. ${ }^{10}$ Because dignity rights are universal, they do not balkanize society or disrupt social cohesion. ${ }^{11}$

Kenji Yoshino's article, The New Equal Protection, urges legal scholars and lawyers to consider using dignity-based arguments rather than asserting group-based equality claims. ${ }^{12}$ Yoshino agrees with the Court's contention that group-based equal protection divides society, and he offers literature from social capital theorists-primarily Robert Putnam-to support his arguments. ${ }^{13}$ Yoshino, however, finds hope for vulnerable classes in dignity-based claims, noting the successful litigation by petitioners in Lawrence v. Texas and Planned Parenthood of Southeastern Pennsylvania v. Casey. ${ }^{14}$

Although Yoshino's work has received a tremendous amount of attention from legal scholars, other theorists, such as Rebecca L. Brown, suggested before Yoshino that liberty and dignity arguments could become the "new equality." 15 Also, Leslie Meltzer Henry's recent research demonstrates that the Court has referred to dignity as a basis for deciding cases since the 1940s. ${ }^{16}$ Notably, the word "dignity" has recently appeared with greater frequency in Supreme Court opinions. ${ }^{17}$

${ }^{6}$ See sources cited supra note 5.

${ }^{7}$ Yoshino, The New Equal Protection, supra note 5, at 751-76 (discussing social cohesion, diversity, and equal protection).

${ }^{8}$ Id.

${ }^{9} I d$. at 776-85 (discussing new dignity doctrines).

${ }^{10} \mathrm{Id}$. at 793 (dignity doctrine "stresses the interests we have in common as human beings rather than the demographic differences that drive us apart”).

${ }^{11}$ Id.

12 Id.

${ }^{13}$ Id. at 751-54 (discussing "pluralism anxiety” and borrowing from Robert Putnam's research).

${ }^{14}$ Id. at 777-81 (discussing Lawrence v. Texas, 539 U.S. 558 (2003)); id. at 783 (discussing Planned Parenthood of Southeastern Pennsylvania v. Casey, 505 U.S. 833 (1992)).

${ }^{15}$ Rebecca L. Brown, Liberty, the New Equality, 77 N.Y.U. L. REV. 1491 (2002).

${ }^{16}$ Leslie Meltzer Henry, The Jurisprudence of Dignity, 160 U. PA. L. REV. 169, 178-79 (2011) (arguing that over 100 of the 220 Supreme Court cases that contain the word "dignity" were decided in the last 20 years).

${ }^{17}$ Id. 
The Court has never stated that it has abandoned the suspect class doctrine. Silence regarding doctrinal changes, however, does not obscure reality. In recent case law, equal protection has become a toothless instrument for advocates of social justice and victims of subordination. The Court has not recognized a new suspect class since $1977 .{ }^{18}$ Also, the Court has repeatedly rejected compelling arguments that certain politically and socially vulnerable groups constitute a suspect class. ${ }^{19}$

The Court has also refused to interpret the Equal Protection Clause as a legal prohibition of subordination. Instead, the Court narrowly construes equal protection as barring only state action that differentiates on the basis of prohibited categories. ${ }^{20}$ The Court adheres to this doctrinal choice regardless of whether the state action seeks to remedy discrimination, ameliorate subordination, or to promote public benefits, such as academic diversity. ${ }^{21}$ Accordingly, the Court's rulings have severely curtailed the usefulness of the Equal Protection Clause as a source of redress for vulnerable classes. ${ }^{22}$

Many factors, other than fear of balkanization, could explain the Court's dismantling of group-based equal protection. Some critical theorists, for example, contend that the Court has abandoned equal protection analysis because a majority of the justices either harbor hostility toward the classes who seek judicial solicitude or generally disfavor civil rights litigation. ${ }^{23}$ Other theorists offer less damning reasons, finding, for example, that structural concerns, like federalism and separation of powers, explain the Court's rejection of a robust equal protection analysis. ${ }^{24}$ Structural concerns and judicial bias, however, can operate simultaneously. Throughout American legal history, opponents of racial justice have frequently invoked states' rights and federalism concerns in order to defend racial subordination. ${ }^{25}$ Furthermore, the Court's rigid applica-

18 See Yoshino, The New Equal Protection, supra note 5, at 757.

19 See infra text accompanying notes 63-77.

${ }^{20}$ See infra text accompanying notes 323-30.

${ }^{21}$ Id.

${ }^{22}$ See R. Siegel, Why Equal Protection No Longer Protects, supra note 2.

${ }^{23}$ See, e.g., Jed Rubenfeld, The Anti-Antidiscrimination Agenda, 111 YALE L.J. 1141, 1142 (2002) (suggesting that a "unifying thread behind the Court's innovative constitutional case law" is "an anti-antidiscrimination agenda, deeply felt but as yet poorly theorized”); Girardeau Spann, Affirmative Action and Discrimination, 39 How. L.J. 1, 72 (1995) (arguing that the Court's decision to negate an affirmative action plan results from "good, old-fashioned racial discrimination, pure and simple”). Cf. Amy Ronner, Scouting for Intolerance: The Dale Court's Resurrection of the Medieval Leper, 11 L. \& SEXUALITY 53 (2002) (arguing that homophobia impacts Court decisions regarding access to public accommodations by gays and lesbians).

${ }^{24}$ Hutchinson, Inversion of Privilege and Subordination, supra note 3, at 673-76 (discussing institutional concerns and equal protection).

25 See, e.g., Erwin Chemerinsky, Have the Rehnquist Court's Federalism Decisions Increased Liberty?, 21 HuM. RTS. 3, 9 (2002) ("Segregation and dis- 
tion of strict scrutiny review of race-conscious state action complicates the structural explanation. According to the Court, racial classifications are presumably unconstitutional, regardless of context or purpose. This rigid stance toward state and federal policies undermines structural arguments in defense of a restrained equal protection doctrine. ${ }^{26}$

While many factors might explain the Court's retreat from the suspect class doctrine, this Article primarily addresses the balkanization argument. From an empirical standpoint, legal scholars have persuasively demonstrated that the Court and individual justices have invoked a fear of balkanization as a reason for rejecting the equal protection claims of vulnerable classes or for invalidating race-conscious state action. ${ }^{27}$ This Article does not quarrel with this empirical observation. Instead, this Article contends that the Court's stated fear of balkanization requires closer scrutiny. Scholars who write on this subject tend to take the Court's stated anxiety regarding social conflict at face value. For several reasons, however, legal theorists should subject the Court's contention to a more rigorous analysis.

First, the Court fails to make a convincing argument that groupbased equal protection actually causes balkanization. In fact, the Court has not supported this assertion with empirical research but instead relies primarily upon its own precedent. Second, even if group-based equal protection leads to balkanization, this fact alone does not justify withdrawing protection from vulnerable classes. The Court appears to believe that social cohesion is more important than racial justice, but this argument is hardly beyond debate. Indeed, the historical context in which the Fourteenth Amendment was ratified suggests that racial equality is a paramount interest of states and Congress, and the Supreme Court should not compromise racial justice in order to appease individuals who support the status quo of racial inequality and for whom racial redress causes tension.

crimination were defended less on the grounds that they were desirable practices, and more in terms of the states' rights to choose their own laws concerning race relations.”); Norman W. Spaulding, Constitution as Countermonument: Federalism, Reconstruction, and the Problem of Collective Memory, 103 COLUM. L. REV. 1992, 2033 (2003) ("Respect for state sovereignty . . became a powerful, publicly acceptable, and legally authoritative framework for expressing the rather perverse desire to abandon the principles of equality implicated in the War for the sake of reconciliation with southern whites.”); Timothy Zick, Statehood as the New Personhood: The Discovery of Fundamental "States' Rights," 46 WM. \& MARY L. REV. 213, 316 (2004) (observing that "the phrase 'states' rights,' for many, conjures a host of negative associations, including, for some, virulent racism”).

${ }^{26}$ Hutchinson, Inversion of Privilege and Subordination, supra note 3, at 674-79 (questioning transparency of the Court's invocation of institutional concerns in equal protection cases).

${ }^{27}$ See infra text accompanying notes 39-80. 
[Vol. 22:1

Legal scholars who have analyzed the Court's fear of balkanization have provided much more substantive justification for abandoning the suspect class doctrine than the Court's summary conclusion. Nevertheless, many of these scholars take the Court's stated fear of social tension at face value. Yoshino, however, offers empirical research in social capital studies that purportedly demonstrates the balkanizing impact of group-based identity and the negative impact of multiculturalism. ${ }^{28} \mathrm{~A}$ number of social scientists, however, have conducted empirical studies that raise serious questions regarding the validity of the claims that social capital theorists make regarding groups and social cohesion. ${ }^{29}$ The quality and volume of this research greatly diminishes the usefulness of social capital theory as a justification for discarding group-based equality.

In addition to questioning social capital theorists' arguments about groups and social cohesion, social scientists have conducted numerous empirical studies that provide a more accurate account of the dynamics of the Court's equal protection doctrine, particularly with respect to race and racism. For example, social psychology studies demonstrate the pervasiveness and resilience of group-based dominance. ${ }^{30}$ Social psychologists have also conducted studies that demonstrate that whites are more likely to support colorblindness and assimilation than persons of color and that persons of color are more likely to support group-based identities and multiculturalism than whites. ${ }^{31}$ Thus, to the extent that tension arises from group-based equality, this tension is one-sided: it largely causes stress among dominant racial groups.

Furthermore, social psychology research demonstrates that societies often create or promote legitimizing myths or collective narratives to justify group domination. ${ }^{32}$ With respect to race relations in the United States, colorblindness helps to justify unequal distribution of power among racial groups. ${ }^{33}$ If race is an insignificant social characteristic, then it should not influence social policy.

Also, a recent study indicates that whites believe that they suffer more discrimination than blacks. ${ }^{34}$ This legitimizing myth powerfully impacts the desirability of race-based remedies among whites. If whites believe that they are racial victims, then they will view policies that seek to provide additional resources to persons of color as harming whites.

Furthermore, whites tend to believe that the United States offers equal opportunity for social and economic advancement regardless of

\footnotetext{
${ }^{28}$ See Yoshino, The New Equal Protection, supra note 5, at 751-54.

${ }^{29}$ See infra text accompanying notes 133-80.

${ }^{30}$ See infra text accompanying notes 185-95.

${ }^{31}$ See infra text accompanying notes 195-204.

${ }^{32}$ See infra text accompanying note 195.

33 See infra text accompanying note 207.

${ }^{34}$ See infra text accompanying notes 213-27.
} 
race. People of color do not agree with this contention. ${ }^{35}$ Empirical research finds that people who believe that society has achieved racial equality are particularly uncomfortable with policies that provide redress and remediation to persons of color. ${ }^{36}$ The presumption that the United States has achieved a post-racial status provides strong support for opponents of race-based remedies. The opponents of race-conscious public policies contend that persons of color no longer need relief because the country has eliminated racism.

These empirical findings provide a helpful social context for understanding the Court's equal protection doctrine. Indeed, as this Article will demonstrate, the Supreme Court's equality cases, by impact or intent, mirror the leading legitimizing myths regarding contemporary race relations in the United States that whites tend to believe. Like the white majority, the Court: (1) eschews multiculturalism and prefers colorblindness; (2) believes that group-based identity and equality claims harm society and that individualism is preferable; (3) treats racism as largely vanquished by historical battles and social evolution; and (4) perceives of whites as vulnerable racial victims. ${ }^{37}$ Because current equal protection doctrine mirrors majoritarian perspectives regarding race, legal scholars should closely scrutinize the justifications the Court provides for its decision making. An equal protection doctrine that facilitates racial domination cannot constitute a fair interpretation of the Equal Protection Clause.

This Article encourages lawyers and legal scholars to continue articulating equal protection theories that combat racial inequality. Although dignity-based arguments might offer some relief to subordinate classes, this doctrine alone cannot accomplish all of the work that a robust application of equal protection could achieve. This Article argues that the Court should apply an equal protection doctrine designed to invalidate state action that reinforces the social and political subordination of people of color and other vulnerable classes. Such a doctrine would welcome multiculturalism and group-based identity as necessary elements of a just society. This doctrine would also recognize that the appropriateness of colorblindness or race-consciousness depends upon context. Policies that seek to ameliorate racial inequality do not presumptively violate the Constitution even if they utilize racial classifications. On the other hand, state action that reinforces racial hierarchy violates the Constitution even if it is facially neutral with respect to race. Furthermore, the "newer" equal protection that this Article advocates would rest on the empirically demonstrable reality that race remains a substantial barrier to equality in the United States and that whiteness remains a privileged category.

\footnotetext{
35 See infra text accompanying notes 205-06.

${ }^{36}$ See infra text accompanying notes 205-12.

37 See infra text accompanying notes 227-69.
} 
This doctrine would not mean that all whites are wrong and that all people of color are right. In fact, many whites support multiculturalism, while many people of color do not. Many whites support group-based equality, while many people of color do not. Instead, this doctrine would not structure equal protection to mirror the beliefs that socially dominant groups hold regarding the status of race relations. Thus, it would not privilege any racial group. Instead, it would prioritize equality enhancement over the preservation of hierarchy. This goal does not offend equal protection.

This Article evolves in four principal Parts. Part I generally analyzes and accepts the empirical claim that the Court has indeed pointed to a fear of balkanization in order to justify a retreat from group-based equal protection. First, Part I demonstrates that the balkanization discourse has appeared frequently in three areas of equal protection case law, namely, the application of colorblindness and antidifferentiation; the requirement of discriminatory intent in equal protection doctrine; and the Court's refusal to recognize additional suspect classes despite the persuasiveness of claims some vulnerable groups have made. Part I then briefly examines the historical use of dignity arguments in judicial opinions and analyzes the recent escalation of such arguments. Next, Part I examines the claim that the Court has moved to dignity-based due process claims and away from group-based equal protection claims because it fears balkanization. Finally, Part I considers how social capital theory has informed legal scholarship that supports dignity-based due process claims over group-based equal protection.

Part II considers whether social capital literature justifies the Court's concern with balkanization and its retreat from group-based equal protection. Part II first examines social capital literature that finds cultural pluralism harmful to society, but argues that this literature does not justify the Court's fear of balkanization and its movement away from the suspect class doctrine. Robert Putnam, a leading social capital theorist (and the scholar whose work most influenced Yoshino's The New Equal Protection), forcefully rejects the argument that his scholarship compels the rejection of group-based equal protection and the end of policies designed to promote racial diversity and equality. Instead, Putnam contends that racial and ethnic diversity engenders many important societal benefits. While Putnam has retreated somewhat from his claims regarding the destabilizing impact of multiculturalism, he now argues that a younger generation of Americans has found a common identity and is reengaging in political and civic activity-despite racial and ethnic differences. Part II then examines numerous social science studies that debunk or raise questions regarding Putnam's methodology and findings as well as the research of other social capital theorists.

Part III considers whether the Court's evasion of the suspect class doctrine prevents balkanization or facilitates racial subordination. Part III first analyzes the work of social psychologists, who, unlike social capital theorists, have studied the relationship of groups and society for 
nearly a century. Part III demonstrates that many social psychologists consider group-based identity an essential dimension of human societies. Furthermore, group-based domination has always existed in human societies. Part III then discusses various empirical studies regarding the substance of contemporary race relations in the United States. Specifically, Part III examines social psychology studies that find that whites are much more likely than persons of color to embrace colorblindness over multiculturalism and that persons of color are much more likely than whites to embrace multiculturalism over colorblindness. Furthermore, empirical research demonstrates that whites tend to support ideals of individualism over group identity, while persons of color favor group identity over individualism. Part III also demonstrates that whites tend to believe that racism no longer remains a significant barrier to social and economic advancement, while people of color believe that race is a substantial obstacle to equal opportunity. Next, Part III analyzes empirical research that finds that whites believe that they are racial victimspossibly to a greater extent than persons of color-but that people of color do not share this opinion. Part III also discusses how whites' embrace of these positions regarding racism helps to justify pervasive racial inequality. Part III then compares dominant group ideas regarding race with the Court's equal protection doctrine to demonstrate that the Court has implemented each of the four system-preserving beliefs that whites have regarding race relations. In other words, the Court's equal protection doctrine enforces dominant racial perspectives that legitimize racial inequality. The incorporation of these viewpoints into equal protection doctrine facilitates racial inequality in two ways. First, it justifies the judicial invalidation of state action that seeks to reduce racial hierarchy. Second, it shields from judicial invalidation facially neutral laws or policies that impose serious harms upon persons of color.

Part IV advocates for the construction of a "newer" equal protection that actually protects vulnerable classes rather than facilitating racial inequality. Part IV maps out the contours of this doctrine, observing that it would rest on a firm empirical understanding of United States race relations, including the value of multiculturalism, the inevitability and importance of group identity, the persistence of racism and racial inequality, and the privileged status of whiteness. While this newer equal protection theory would not seek to supplant dignity claims, this Article does recognize the limits of dignity arguments and the need for advocates of social justice to utilize equal protection alongside other types of legal doctrines. 


\section{BALKANIZATION AND EQUAL PROTECTION}

Several legal scholars contend that the Court's fear of balkanization has impacted equal protection doctrine. ${ }^{38}$ This Part finds substantial support for these scholars' empirical claim that evading balkanization has become a central component of equal protection doctrine. Some of these scholars have offered empirical research to support the Court's fear that group-based equal protection polarizes society, including studies conducted by social capital theorists, particularly Robert Putnam (whose research has influenced scholars within and outside of the legal academy). ${ }^{39}$ Putnam contends that multiculturalism diminishes civic engagement and trust among members of society and causes people to withdraw into themselves. Putnam's research, if accurate, could potentially justify the Court's retreat from the suspect class doctrine. ${ }^{40}$

\section{A. Balkanization: The Empirical Claim}

The Court has indisputably cited a concern with balkanization as a reason to reject group-based equal protection claims. This fear of social tension has justified the Court's application of a very rigid strict scrutiny of state action that uses racial classifications to remedy current and historical discrimination or that seeks to promote a public good, such as diversity in higher education. The Court has also invoked balkanization or opposition to group remedies as a basis for requiring discriminatory intent in equal protection cases and for declining to find any new suspect classes.

1. Colorblindness, Affirmative Action, and Balkanization

Members of the Court began referring to balkanization in the first case the Court decided that challenged an affirmative action program. In Regents of the University of California v. Bakke, Justice Powell rejected the university's argument that the Court should not apply strict scrutiny to its race-based affirmative action program. ${ }^{41}$ The university argued that because whites do not constitute a politically vulnerable class, extraordi-

${ }^{38}$ See R. Siegel, From Colorblindness to Antibalkanization, supra note 5; Yoshino, The New Equal Protection, supra note 5.

${ }^{39}$ Yoshino, The New Equal Protection, supra note 5. See Robert D. Putnam, E Pluribus Unum: Diversity and the Community in the Twenty-First Century, 30 SCANDinaVian Pol. STUd. 137 (2007) [hereinafter Putnam, E Pluribus Unum].

${ }^{40}$ Putnam, E Pluribus Unum, supra note 39.

${ }^{41}$ Regents of Univ. of Cal. v. Bakke, 438 U.S. 265, 288 (1978) (writing for the plurality and disagreeing with the university's assertion "that the court below erred in applying strict scrutiny to the special admissions program because white males, such as respondent, are not a 'discrete and insular minority' requiring extraordinary protection from the majoritarian political process”). 
nary intervention by the Court into the political process that led to the policy was not warranted. ${ }^{42}$

Powell, however, argued that the Constitution forecloses a "twoclass theory" of equal protection that treats blacks as "special wards entitled to a degree of protection greater than that accorded others."43 Although the Court had previously relied upon footnote four of Carolene Products $v$. United States as a justification for applying strict scrutiny to policies that harm discrete and insular minorities, Powell argued that all racial classifications should receive strict judicial scrutiny. ${ }^{44}$

Powell defended his position, in part, on the grounds that if the Court were to determine which racial groups lacked political power, this would inevitably lead to competing and shifting claims of discrimination by numerous groups, which would require an analysis beyond the competence of the Court-even if "socially desirable." 45 According to Powell, toleration of some race-based policies and intolerance of others could "exacerbate racial and ethnic antagonisms, rather than alleviate them." ${ }^{46}$

During the Rehnquist Court, several justices, including Justices O'Connor, Scalia, and Thomas, contended that racial classifications divide society. In City of Richmond v. J.A. Croson Co., for example, O'Connor argued that racial classifications can "lead to a politics of racial hostility" and that the dissent's "watered-down version of equal protection review, effectively assures that race will always be relevant in American life." 47 O’Connor also suggested that even if the Court should more rigorously protect politically vulnerable classes under a theory of equal protection, then this case would qualify for strict scrutiny because Richmond blacks occupied five of nine seats on the city council and constituted fifty percent of the local population. ${ }^{48}$ As a result, blacks dominated whites, rendering them socially and politically vulnerable. ${ }^{49}$

Justice Scalia's concurrence in Croson expresses an unmistakable belief that race-conscious remedial policies cause racial divisions:

${ }^{42} I d$. at 290.

${ }^{43} \mathrm{Id}$. at 295.

${ }^{44} I d$. at 291 ("Racial and ethnic distinctions of any sort are inherently suspect and thus call for the most exacting judicial examination.”); United States v. Carolene Prods., 304 U.S. 144, 153 n.4 (1938).

${ }^{45}$ Bakke, 438 U.S. at 297. See also id. at 295-96 (“[T] whe white 'majority' itself is composed of various minority groups, most of which can lay claim to a history of prior discrimination at the hands of the State and private individuals. Not all of these groups can receive preferential treatment and corresponding judicial tolerance of distinctions drawn in terms of race and nationality, for then the only 'majority' left would be a new minority of white Anglo-Saxon Protestants.”).

${ }^{46}$ Id. at 298-99

${ }^{47}$ City of Richmond v. J.A. Croson Co., 488 U.S. 469, 493, 495 (1989).

${ }^{48} \mathrm{Id}$. at 495.

${ }^{49}$ Id. at $495-96$. 
Racial preferences appear to "even the score" (in some small degree) only if one embraces the proposition that our society is appropriately viewed as divided into races, making it right that an injustice rendered in the past to a black man should be compensated for by discriminating against a white. ${ }^{50}$

Justice Thomas makes a similar observation in his concurring opinion in Adarand Constructors v. Peña. ${ }^{51}$ Thomas describes affirmative action as "racial paternalism" and asserts that such policies have disastrous effects upon blacks and social harmony. ${ }^{52}$ According to Thomas, policies of affirmative action:

[E]ngender attitudes of superiority or, alternatively, provoke resentment among those who believe that they have been wronged by the government's use of race. These programs stamp minorities with a badge of inferiority and may cause them to develop dependencies or to adopt an attitude that they are "entitled" to preferences. ${ }^{53}$

As Reva Siegel has argued, the Court's contention that race-based state action divides society has continued during the Roberts era. ${ }^{54}$ In Parents Involved in Community Schools v. Seattle School District Number 1, Chief Justice Roberts's plurality opinion culls numerous quotations from Supreme Court precedent in order to portray governmental usage of race for socially productive purposes as promoting the same divisions, stereotypes, and harms caused by Jim Crow-era segregation. ${ }^{55}$ And while Justice Kennedy disagrees with the plurality's conclusion that states do not have a compelling interest in remedying the geographic isolation of students of color, he argues that racial classifications can diminish social cohesion:

Governmental classifications that command people to march in different directions based on racial typologies can cause a new divisiveness. The practice can lead to corrosive discourse, where race serves not as an element of our diverse heritage but instead as a bargaining chip in the political process. ${ }^{56}$

${ }^{50} \mathrm{Id}$. at 528 (Scalia J., concurring).

${ }^{51}$ Adarand Constructors v. Peña, 515 U.S. 200 (1995).

${ }^{52} \mathrm{Id}$. at 240.

${ }^{53} \mathrm{Id}$. at 241.

${ }^{54}$ See R. Siegel, From Colorblindness to Antibalkanization, supra note 5 (discussing the use of balkanization discourse in C.J. Roberts Court opinions).

${ }^{55}$ Parents Involved in Cmty. Sch. v. Seattle Sch. Dist. No. 1, 551 U.S. 701, 741-42 (2007).

${ }^{56}$ Id. at 797. 
Kennedy describes race as a political trump card, rather than a basis for distributive justice. Although Kennedy strives to find a middle ground between the dissent and the plurality, he ultimately concludes that governmental policies that utilize racial categories most likely harm, rather than improve, society.

As the Court's statements regarding social disruption indicate, the justices generally disapprove of policies that treat people as members of groups rather than as individuals. ${ }^{57}$ The Court demonstrates its disdain for group identity by holding, particularly in affirmative action cases, that the Constitution secures individual rights-not group rights. ${ }^{58}$ If the Court refuses to validate group-based identity and rights, then, presumably, it can prevent the erosion that racial categorization causes.

\section{Discriminatory Intent Rule}

To prevail on an equal protection claim, the Court requires plaintiffs to demonstrate that the defendant acted with discriminatory intent. Generally, when courts apply this rule, they do not find evidence of discriminatory impact probative of discriminatory intent. Unless the pattern of discrimination is unmistakably a reflection of an improper motive, plaintiffs will need to provide some other circumstantial evidence of defendants' intent to discriminate. ${ }^{59}$

The Court has offered several justifications for requiring discriminatory intent, one being that an impact standard would raise substantial institutional concerns, such as separation of powers and federalism. ${ }^{60}$ Because numerous facially neutral policies impact vulnerable racial groups, the Court must require additional evidence of intent in order to avoid aggrandizing the judiciary at the expense of state legislatures and Congress. ${ }^{61}$

${ }^{57}$ See S. Siegel, Race-Conscious Student Assignment Plans, supra note 5 (linking rigid analysis in affirmative action cases with Court's disdain for policies that overly emphasize group membership).

${ }^{58}$ Jack Greenberg, Affirmative Action in Higher Education: Confronting the Condition and Theory, 43 B.C. L. REV. 521, 580-81 (2002) (discussing Court's references to "group rights" in affirmative action cases).

${ }^{59}$ See generally Sheila Foster, Intent and Incoherence, 72 TUL. L. REV. 1065 (1998) (analyzing the discriminatory intent requirement); David A. Strauss, Discriminatory Intent and the Taming of Brown, 56 U. CHI. L. REV. 935 (1989).

${ }^{60}$ Hutchinson, Inversion of Privilege and Subordination, supra note 3, at 677 (discussing institutional concerns and the discriminatory intent rule).

${ }^{61}$ See Washington v. Davis, 426 U.S. 229, 248 (1976) ("A rule that a statute designed to serve neutral ends is nevertheless invalid, absent compelling justification, if in practice it benefits or burdens one race more than another would be far-reaching and would raise serious questions about, and perhaps invalidate, a whole range of tax, welfare, public service, regulatory, and licensing statutes that may be more burdensome to the poor and to the average black than to the more affluent white.”). 
The Court also applies the discriminatory intent rule because it has found that the Equal Protection Clause does not protect group rights. Although the Court has not analyzed this issue at length, several scholars have observed that disparate impact theories rest most comfortably on a constitutional theory of group rights. ${ }^{62}$ Because the Court, however, believes that group identity and group-based equal protection divide society, it has generally rejected disparate impact as proof of discrimination in equal protection cases. ${ }^{63}$ Even though equal protection plaintiffs who present evidence of discriminatory impact do not formally plead theories of collective rights, the Court, nonetheless, emphasizes the need for individualized proof of discrimination. ${ }^{64}$

\section{The End of Suspect Classes}

The Court's fear of balkanization has led to a third doctrinal development: the demise of the suspect class doctrine. Two doctrinal moves effectively ended the suspect class doctrine. First, the Court has declined to recognize new suspect classes, despite compelling circumstances that could have justified expansion of the doctrine. Second, the Court has applied heightened scrutiny symmetrically, extending heightened scrutiny to whites and persons of color and women and men, despite the groups having very different histories with respect to group domination. These two developments both derive from the Court's fear of balkanization.

\section{a. Failure to Recognize New Suspect Classes}

The Court has often, though not consistently, used a four-factor test to determine whether a group qualifies as a suspect class. Specifically, the Court considers whether the group: (1) has suffered from a history of discrimination; (2) lacks political power; (3) suffers discrimination due to an immutable characteristic; and (4) experiences discrimination on the basis of a trait that bears no relationship to its members' ability to per-

62 See, e.g., Owen Fiss, Groups and the Equal Protection Clause, 5 PHIL. \& PuB. AFF. 108, 141-46 (1976) (advocating group-based equal protection doctrine in order to accommodate claims of discriminatory effects); Yoshino, The New Equal Protection, supra note 5, at 765 (recognizing that pluralism anxiety explains the discriminatory intent rule, in part, though not explicitly mentioned in Court rulings and observing that once the Court "imported this equal protection framework into the free exercise context . . . the Justices did avert to such anxiety”).

63 See, e.g., McCleskey v. Kemp, 481 U.S. 279, 317 n.39 (1987) ("Finally, in our heterogeneous society the lower courts have found the boundaries of race and ethnicity increasingly difficult to determine.”).

${ }^{64}$ See id. at 292 ("Thus, to prevail under the Equal Protection Clause, McCleskey must prove that the decisionmakers in his case acted with discriminatory purpose.”). 
form or contribute to society. ${ }^{65}$ This test, first detailed in Justice Brennan's opinion for the plurality in Frontiero v. Richardson, draws from the political process theory alluded to in footnote four of Carolene Products. ${ }^{66}$ The Court uses this test to determine whether it should apply a more stringent level of review when certain classes, due to their political powerlessness, cannot protect themselves from abusive political decision making. ${ }^{67}$ Dominant classes, by contrast, do not warrant heightened protection because they do not experience subjugation in the political process. ${ }^{68}$

The Court has inconsistently applied the Frontiero test, and many of the component factors remain undertheorized. ${ }^{69}$ Most importantly, however, the Court has effectively discontinued using this doctrine to find new suspect classes. Many scholars have persuasively argued that the suspect class doctrine now operates as a gatekeeper instead of a formula used to determine which groups suffer from political oppression. ${ }^{70}$

65 See Noreen Farrell \& Genevieve Guertin, Old Problem, New Tactic: Making The Case for Legislation to Combat Employment Discrimination Based on Family Caregiver Status, 59 Hastings L.J. 1463, 1481-82 (2008) ("[The heightened scrutiny] factors include (1) the possession of an immutable characteristic by members of the protected class, (2) the existence of a history of discrimination against members of the class, (3) the relevance of the characteristic to legitimate decision making, and (4) the political power of the class.”) (citation omitted).

${ }^{66}$ See Frontiero v. Richardson, 411 U.S. 677, 684-88 (1973) (plurality opinion) (arguing that women constitute a suspect class); United States v. Carolene Prods., 304 U.S. 144, 153 n.4 (1938) (suggesting a more "searching judicial inquiry" of laws that stem from "prejudice against discrete and insular minorities”).

67 JOHN HART ELY, DEMOCRACY AND Distrust: A THEORY OF JUDICIAL REVIEW 135-79 (1980) (considering prejudice against “minority” groups a political process failure).

${ }^{68} \mathrm{Id}$.

${ }^{69}$ See Jane Schacter, Ely at the Alter: Political Process Theory Through the Lens of the Marriage Debate, 109 Mich. L. REV. 1363, 1376 (2011) ("In the course of making political powerlessness an element of equal protection doctrine, the justices have had very little to say about what the idea of political powerlessness means and requires, and even less to say about the underlying idea of democracy informing the Court's assessment of the political process. Supreme Court opinions simply contain very little by way of exposition.”); Kenji Yoshino, Assimilationist Bias in Equal Protection: The Visibility Presumption and the Case of “Don't Ask, Don't Tell," 108 YALE L.J. 485, 565 (1998) [hereinafter Yoshino, Assimilationist Bias] (arguing that the standards for heightened scrutiny “are applied inconsistently across contexts”).

${ }^{70}$ Yoshino, Assimilationist Bias, supra note 69, at 558 (arguing that the Court uses the suspect class doctrine in order to "limit[] the number of groups deemed to deserve the courts' solicitude”); Darren Lenard Hutchinson, Not Without Political Power: Gays and Lesbians, Equal Protection, and the Suspect Class Doctrine, 65 ALA. L. REV. 975, 993 (2014) [hereinafter Hutchinson, Not 
The Court has cited numerous structural reasons, including federalism and separation of powers, to justify its refusal to find new suspect classes. Once the Court decides that a group constitutes a suspect class, this finding would imply the judicial invalidation of most or all state and federal action that discriminates against the group. ${ }^{71}$ The suspect class doctrine, if successfully asserted by a particular class, would give the Court enormous oversight of state and federal laws that discriminate against that group. To prevent such augmentation of the judicial power, the Court applies the suspect class doctrine with great cautionarguably, to the point of discarding the doctrine altogether.

Institutional concerns, however, do not fully explain the Court's refusal to find new suspect classes. Instead, the Court has also expressed discomfort with group equality claims as a basis for denying suspect class status to certain groups - even when they have made a persuasive case for application of heightened protection. In Cleburne v. Cleburne Living Center, for example, the Court reviewed a Fifth Circuit ruling that held that a class of developmentally disabled persons qualifies as a quasi-suspect class, entitled to intermediate scrutiny. ${ }^{72}$ The Court reversed the portion of the appellate ruling that found quasi-suspect status, although it affirmed the judgment invalidating the discriminatory municipal ordinance. ${ }^{73}$ The Court expressed a concern that creating a new suspect class would lead to a proliferation of group-based equality claims and create an unmanageable situation for the Court. ${ }^{74}$

Similarly, in San Antonio Independent School District v. Rodriguez, the Court refused to treat people who live in poor school districts as a suspect class. ${ }^{75}$ The Court held that numerous difficulties would arise from an effort to recognize this class as a group and doing so could lead to an endless array of claims for group redress. ${ }^{76}$

Without Political Power] (discussing gatekeeping nature of suspect class doctrine).

${ }^{71}$ See, e.g., Cleburne v. Cleburne Living Ctr., 473 U.S. 432, 444-45 (1985) (expressing reluctance to apply heightened scrutiny due to chilling effect on federal legislation).

${ }^{72}$ See id. at 432.

${ }^{73}$ See generally id.

${ }^{74}$ See id. at 445-46 ("Fourth, if the large and amorphous class of the mentally retarded were deemed quasi-suspect for the reasons given by the Court of Appeals, it would be difficult to find a principled way to distinguish a variety of other groups who have perhaps immutable disabilities setting them off from others, who cannot themselves mandate the desired legislative responses, and who can claim some degree of prejudice from at least part of the public at large. One need mention in this respect only the aging, the disabled, the mentally ill, and the infirm. We are reluctant to set out on that course, and we decline to do so.”).

${ }^{75}$ San Antonio Indep. Sch. Dist v. Rodriguez, 411 U.S. 1, 28 (1973).

${ }^{76} \mathrm{Id}$. at 27-28 ("Assuming a perfect correlation between district property wealth and expenditures from top to bottom, the disadvantaged class might be 
Ironically, in Bakke, Justice Powell, who strongly condemned groupbased equal protection in the context of race, explicitly endorsed the class approach for "other" groups seeking judicial solicitude. ${ }^{77}$ Nonetheless, the Court has effectively retreated from this doctrine as well, leaving many vulnerable groups susceptible to majoritarian abuses.

\section{b. Class-to-Classification Shift}

The Court's symmetrical application of strict and heightened scrutiny in equal protection cases also marks a retreat from the suspect class doctrine. Rather than protecting vulnerable classes, such as blacks or women, from discrimination, contemporary equal protection disallows the use of certain classifications, like race or sex, by state actors. ${ }^{78}$ The class-to-classification shift in equal protection doctrine demonstrates that the Court has abandoned the suspect class doctrine literally and substantively. Nonetheless, the Court still has not announced a standard for determining whether a classification on its own is constitutionally suspicious. Instead, the Court merely points to the historical subordination of women and persons of color to explain why it should follow a classification approach. ${ }^{79}$ In other words, the Court extends judicial solicitude to persons, like white men, who have not suffered historical or present-day subordination, because the historical subjugation of people of color and women makes race and sex inappropriate bases for public policy. That a long history of racial oppression justifies invalidation of policies designed to alleviate the harms of this history offers compelling evidence that equal protection no longer provides justice for racial and ethnic minorities. ${ }^{80}$

viewed as encompassing every child in every district except the district that has the most assessable wealth and spends the most on education.”); id. at 28 ("However described, it is clear that appellees' suit asks this Court to extend its most exacting scrutiny to review a system that allegedly discriminates against a large, diverse, and amorphous class, unified only by the common factor of residence in districts that happen to have less taxable wealth than other districts.").

${ }^{77}$ Regents of Univ. of Cal. v. Bakke, 438 U.S. 265, 290 (1978) (arguing that the suspect class factors "may be relevant in deciding whether or not to add new types of classifications to the list of 'suspect' categories" but that "[r]acial and ethnic classifications . . . are subject to stringent examination without regard to these additional characteristics.") (citations omitted).

${ }^{78}$ See Nice, supra note 1 , at 1400.

${ }^{79}$ See, e.g., Adarand Constructors v. Peña, 515 U.S. 200, 213-18 (1995) (discussing numerous cases involving discrimination against persons of color to justify applying strict scrutiny to all racial classifications).

${ }^{80}$ See, e.g., City of Richmond v. J.A. Co. 488 U.S. 469, 528-29 (Marshall, J., dissenting) (arguing that "[i]t is a welcome symbol of racial progress when the former capital of the Confederacy acts forthrightly to confront the effects of racial discrimination in its midst" but lamenting that "[a] majority of this Court holds . . . that the Equal Protection Clause . . . blocks Richmond's initiative”); 


\section{B. Dignity and the Supreme Court}

Currently, equal protection doctrine denies substantial protection to vulnerable social groups. Nevertheless, in a few recently decided cases, dignity-based claims brought under the Due Process Clause have offered some hope to disadvantaged groups, particularly LGBT individuals. The successful use of dignity arguments in social justice litigation has generated a substantial amount of academic literature, which this section analyzes.

\section{Historical Usage of "Dignity" in Supreme Court Opinions}

Although recent academic literature regarding the Court's use of dignity analysis to decide due process claims might leave the impression that it is a novel judicial development, dignity-based outcomes have a long historical presence in Supreme Court cases. Leslie Meltzer Henry's work, The Jurisprudence of Dignity, reveals that the word "dignity" appears in over nine hundred Supreme Court opinions. ${ }^{81}$ Furthermore, the Court has made appeals to dignity in numerous contexts outside of the Due Process Clause. ${ }^{82}$ And while many theorists have criticized the Supreme Court for failing to provide a concrete definition of dignity, the Court has relied upon this concept with greater frequency in recent case law. ${ }^{83}$

Rejecting the essentialist and reductionist approaches she sees in current scholarship, Henry canvasses all of the references to dignity in Supreme Court cases in order to determine the different concepts the Court has used dignity to express. Henry agrees that the Court has used dignity-based doctrines to protect liberty interests, such as abortion rights and sexual conduct, but the Court has also made appeals to dignity in order to defend "institutional status," "equality," "personal integrity," and "collective virtue." ${ }^{4}$ Thus, as Henry concludes, dignity has a contingent meaning, and the Court uses the term primarily to emphasize or "give weight to the substantive interests that are implicated in specific contexts." 85

id. at 562 (Blackmun, J., dissenting) ("I never thought that I would live to see the day when the city of Richmond, Virginia, the cradle of the Old Confederacy, sought on its own, within a narrow confine, to lessen the stark impact of persistent discrimination. . . . Yet this Court, the supposed bastion of equality, strikes down Richmond's efforts as though discrimination had never existed or was not demonstrated in this particular litigation.”).

${ }^{81}$ Henry, supra note 16, at 178.

${ }^{82} \mathrm{Id}$. at $172-73$.

${ }^{83} \mathrm{Id}$. at 171 .

${ }^{84} \mathrm{Id}$. at 190.

${ }^{85} \mathrm{Id}$. 


\section{Contemporary Dignity Cases and Academic Reaction}

Henry's work demonstrates that among legal theorists, the Court's use of "dignity" in sovereign immunity cases has received the most analysis. ${ }^{86}$ A more recent strand of scholarship discusses the use of dignity in liberty-based due process litigation. ${ }^{87}$ This set of cases arguably constitutes a new equal protection doctrine because they accomplish some equality norms in the absence of a formal equal protection claim. ${ }^{88}$

The linkage of liberty and dignity has a very long presence in United States political theory, and, more generally, in Greek and Roman philosophy. ${ }^{89}$ With respect to modern history, the first Supreme Court decision to merge liberty and dignity is Thornburgh v. American College of Obstetricians and Gynecologists, which invalidated numerous provisions of a Pennsylvania antiabortion law. ${ }^{90}$ The Court also emphasized dignity in Planned Parenthood of Southeastern Pennsylvania v. Casey. ${ }^{91}$ The joint opinion in Casey describes dignity in very broad terms:

Our law affords constitutional protection to personal decisions relating to marriage, procreation, contraception, family relationships, child rearing, and education. Our cases recognize "the right of the individual, married or single, to be free from unwarranted governmental intrusion into matters so fundamentally affecting a person as the decision whether to bear or beget a child.” Our

${ }^{86} \mathrm{Id}$. at $175 \mathrm{n} .32$ (citing many sources).

${ }^{87}$ Id. at 206-12. This Article assumes for the sake of argument and ease of presentation that the Court has crafted a dignity doctrine. The better argument, however, is that the dignity cases represent a compromise orchestrated by Justice Kennedy, whose relative centrism typically controls the outcome of close cases, such as equal protection and liberty adjudication. See R. Siegel, From Colorblindness to Antibalkanization, supra note 5 (arguing that judicial centrists show the most concern regarding balkanization).

${ }^{88}$ See Henry, supra note 16, at 203, 204-05. See also Yoshino, The New Equal Protection, supra note 5, at 783 (discussing equality dimensions of recent dignity cases).

${ }^{89}$ See Henry, supra note 16, at 206 ("The notion that humans deserve respect as free, autonomous, sovereign, and self-determined agents is so entrenched in American political liberalism that it appears self-evident. Its origins can be traced back to ancient Greece and Rome, where the Stoics were among the first thinkers to connect humans' unique capacity for moral reasoning with their dignity.”) (citations omitted).

${ }^{90}$ See Thornburgh v. Am. Coll. of Obstetricians \& Gynecologists, 476 U.S. 747 (1986), overruled in part by Planned Parenthood of Southeastern Pennsylvania v. Casey, 505 U.S. 833 (1992) (plurality opinion). See also Henry, supra note 16, at 174 n.25 ("[f]ew decisions are more personal and intimate, more properly private, or more basic to individual dignity and autonomy, than a woman's decision . . . whether to end a pregnancy.") (quoting Thornburgh, 476 U.S. at 772) (ellipses in original).

${ }^{91}$ Casey, 505 U.S. 833, 851 (1992). 
precedents "have respected the private realm of family life which the state cannot enter.” These matters, involving the most intimate and personal choices a person may make in a lifetime, choices central to personal dignity and autonomy, are central to the liberty protected by the Fourteenth Amendment. At the heart of liberty is the right to define one's own concept of existence, of meaning, of the universe, and of the mystery of human life. Beliefs about these matters could not define the attributes of personhood were they formed under compulsion of the State. ${ }^{92}$

The Supreme Court, however, has subsequently constrained the reach of Casey. In Washington v. Glucksberg, for example, the Court held that the Due Process Clause does not secure a right to physicianassisted suicide. ${ }^{93}$ The Court specifically rejected the respondents' use of Casey to justify recognition of such a right. ${ }^{94}$ Lawrence v. Texas, which found that "liberty" includes a right to engage in consensual sodomy, renewed scholarly arguments that the Court had created a new, possibly expansive, doctrine that combines concepts of liberty with dignity. ${ }^{95}$

\section{Dignity, Equality, and Pluralism Anxiety}

Although many scholars have discussed the Court's fear of balkanization and the development of a dignity-based liberty doctrine, Kenji Yoshino offers a unique perspective to these debates by merging the issues into one analysis. Yoshino contends that the Court's fear of balkanization—or pluralism anxiety—caused the shift to dignity-based claims. ${ }^{96}$ Yoshino argues that dignity claims can avoid the balkanization associated with group-based equal protection because these claims rest on uni-

92 Casey, 505 U.S. at 851 (internal citations omitted) (emphasis in original).

${ }^{93}$ Washington v. Glucksberg, 521 U.S. 702, 735 (1997).

${ }^{94}$ Id. at 703 ("[A]lthough Casey recognized that many of the rights and liberties protected by the Due Process Clause sound in personal autonomy, it does not follow that any and all important, intimate, and personal decisions are so protected. Casey did not suggest otherwise.”) (internal citations omitted).

95 See Henry, supra note 16 at 211 \& n.215 (citing Nelson Lund \& John O. McGinnis, Lawrence v. Texas, and Judicial Hubris, 102 MicH. L. REV. 1555, 1583 (2004)); Yoshino, The New Equal Protection, supra note 5, at 778-81.

96 Yoshino, The New Equal Protection, supra note 5, at 776 ("The Court has used liberty analysis to mitigate its curtailment of group-based equality analysis. This movement toward liberty has not secured all the ends that would have been available under an extension of the traditional group-based equal protection analysis. Nonetheless, progressives should pay more heed to this move toward liberty. The liberty-based dignity claim has been the Court's way of splitting the difference between a direct extension of equality analysis and its absolute foreclosure."). 
versality and commonality, rather than social distinctions. ${ }^{97}$ Dignity arguments unite, rather than divide society because everyone has a right to privacy; everyone has a right to marry; everyone has a right to engage in consensual sexual behavior, and so forth.

\section{Social Science and Pluralism Anxiety}

To document the harmful impact of pluralism, Yoshino relies primarily upon the work of Robert Putnam, a Harvard political scientist, who has written extensively on social capital. ${ }^{98}$ Scholars have invoked social capital to describe several different concepts. ${ }^{99}$ In Bowling Alone, Putnam's first sustained examination of social capital, he uses the term to describe the macro-benefits of engaged social interaction:

Whereas physical capital refers to physical objects and human capital refers to properties of individuals, social capital refers to connections among individualssocial networks and the norms of reciprocity and trustworthiness that arise from them. In that sense social capital is closely related to what some have called "civil virtue." The difference is that "social capital" calls attention to the fact that civic virtue is most powerful when embedded in a dense network of reciprocal social relations. A society of many virtuous but isolated individuals is not necessarily rich in social capital. ${ }^{100}$

Civic participation, measured by voting rates, community-group membership, social engagement with coworkers, philanthropy, and other variables, concerns Putnam the most. His research finds that the level of civic participation in the United States has declined precipitously since World War II. ${ }^{101}$ Putnam contends that the decline in civic participation will harm society, because social interaction through civic engagement engenders numerous important social benefits, including improvements in education and child welfare, reduction of crime, greater economic prosperity, more health and happiness, and greater democratic participation. ${ }^{102}$

${ }^{97}$ Id. at 793 ("The new equal protection paradigm stresses the interests we have in common as human beings rather than the demographic differences that drive us apart. In this sense, the shift from the 'old' to the 'new' equal protection could be seen as a movement from group-based civil rights to universal human rights.”).

${ }^{98}$ See, e.g., Robert D. Putnam, Bowling Alone: The Collapse AND REVIVAl of AMERICAN COMMUNiTy (2000) [hereinafter PUTNAM, BOWLING AlONE].

${ }^{99} \mathrm{Id}$. at $18-20$.

${ }^{100} \mathrm{Id}$. at 19.

${ }^{101} \mathrm{Id}$. at 31-147.

${ }^{102} \mathrm{Id}$. at 287-350. 
[Vol. 22:1

Bowling Alone attributes much of the post-war decline in civic engagement to broader structural and cultural changes in the United States, such as "pressures of time and money" on "two-career families"; "suburbanization, commuting, and sprawl”; "electronic entertainment," especially television; and a generic category of "generational change" (which Putnam concludes overlaps with the ascendency of television). ${ }^{103}$

In Bowling Alone, Putnam rejects the notion that racism caused the massive reduction in civic engagement since the 1950s. ${ }^{104}$ Recently, however, Putnam links the reduction in civic engagement with the increasing pluralism of the United States population. In a very controversial and highly criticized article, Putnam argues that greater ethnic and racial diversity reduces the general level of trust in society-a precondition of civic engagement-and that this reduction occurs within and across social groups. ${ }^{105}$ According to Putnam, multiculturalism or social pluralism causes individuals of all races to "hunker down" or "to pull in like a turtle."106

It is important to note that Putnam concedes that greater diversityespecially from immigration-produces very important social benefits, including greater creativity, rapid economic growth, a new work force to replace a generation of retirees, and improvement of the standard of living in developing countries through North-South remittances. ${ }^{107}$ Nonetheless, Putnam argues that the negative dimensions of immigration and multiculturalism should cause alarm. In addition to causing social isolation, racial and ethnic diversity, according to Putnam, correlate with:

- Lower confidence in local government, local leaders, and the local news media

- Lower political efficacy-that is, confidence in one's own political influence

- Lower frequency of registering to vote, but more interest and knowledge about politics and more participation in protest marches and social reform groups

- Less expectation that others will cooperate to solve dilemmas of collective action

- Less likelihood of working on a community project

- Lower likelihood of giving to charity or volunteering

- Fewer close friends and confidants

- Less happiness and lower perceived quality of life

${ }^{103} \mathrm{Id}$. at $189-284$.

${ }^{104} \mathrm{Id}$. at 279-80 (discussing racism as a possible factor in the reduction of social capital and rejecting this possibility for several reasons).

${ }^{105}$ Putnam, E Pluribus Unum, supra note 39.

${ }^{106} \mathrm{Id}$. at 149.

${ }^{107}$ Id. at $140-41$. 
- More time spent watching television and more agreement that "television is my most important form of entertainment”108

Finally, Putnam suggests that, in spite of the short-term harms that diversity causes, the United States should not seek to "bleach out" all traces of difference. ${ }^{109}$ Instead, he argues that the United States should tolerate diversity, but manage its potentially negative effects by constructing a more flexible and expansive understanding of what it means to be an American. ${ }^{110}$

\section{Social Capital and Dignity Theorists}

Yoshino explicitly relies upon Putnam's arguments in order to promote the use of dignity doctrine as a substitute for group-based equality claims. ${ }^{111}$ Yoshino contends that dignity arguments could help litigants overcome the limitations of the Court's shrinking equal protection doctrine, including the class-to-classification shift, discriminatory intent rule, and judicial rejection of legislative efforts to remedy discrimination against vulnerable groups. ${ }^{112}$

Other scholars have criticized the suspect class doctrine for causing division and balkanization, without citing social capital theory. ${ }^{113}$ In addition, some theorists have explored the connections between dignity and equality without suggesting that one form of analysis should replace the other. ${ }^{114}$ With respect to using social capital theory to examine equal protection and dignity doctrine, Yoshino's work seems to stand alone. Although social capital theory makes some very provocative claims about the value of civic participation in the United States, this research does not justify judicial abandonment of the suspect class doctrine and groupbased equal protection. Part II elaborates on this position.

\section{EQUAL PROTECTION, DIGNITY, AND GROUPS}

This Part argues that, for several reasons, social capital theory does not justify the Court's retreat from group-based equal protection. First,

${ }^{108}$ Id. at $149-50$.

${ }^{109} \mathrm{Id}$. at 164.

${ }^{110} \mathrm{Id}$. at 163-64 ("[M]y hunch is that at the end we shall see that the challenge is best met not by making 'them' like 'us', but rather by creating a new, more capacious sense of 'we', a reconstruction of diversity that does not bleach out ethnic specificities, but creates overarching identities that ensure that those specificities do not trigger the allergic, 'hunker down' reaction.”).

${ }^{111}$ Yoshino, The New Equal Protection, supra note 5, at 752-54, 774-75, 792-93, 796.

${ }^{112}$ Id. at $776-87$.

${ }^{113}$ EVAN GERSTMANN, THE CONSTITUTIONAL UnderClass: GaYs, LESBIANS, AND THE FAILURE OF ClASS-BASED EQUAL PROTECTION (1999).

${ }^{114}$ Henry, supra note 16, at 199-205. 
Putnam does not believe that this scholarship compels a retreat from group-based equal protection or from group-based identity. Also, social capital theorists, including Putnam, have discussed the benefits of racial and ethnic diversity at length. Furthermore, the social capital literature has generated an avalanche of academic criticism that severely undermines its credibility as a basis for constructing judicial doctrines or as a prescription for managing racial and ethnic diversity.

\section{A. Social Capital Literature Does Not Justify a New Equal Protection}

Supreme Court justices and several legal scholars contend that traditional class-based equal protection doctrine divides society and leads to balkanization. On the surface, social capital literature provides some support for this position. For several reasons, however, social capital theory does not justify the Court's retreat from class-based equal protection.

\section{Robert Putnam Does Not Believe His Scholarship Justifies Opposition to Group-Based Egalitarian Policies}

In Fisher v. University of Texas, the Court remanded the case to the Fifth Circuit with instructions to apply the correct level of scrutiny to a university's affirmative action program. ${ }^{115}$ Abigail Thernstrom, Stephan Thernstrom, Althea K. Nagai, and Russell Nieli filed an amicus brief in favor of the petitioner Abigail Fisher and in opposition to the university's use of affirmative action. ${ }^{116}$ The brief challenges the argument made by the respondent, and validated by Court precedent, that racial diversity fosters cross-racial understanding and other compelling benefits for society. ${ }^{117}$ To support this position, the Thernstrom brief cites to Putnam's article E Pluribus Unum. The brief relies upon Putnam's findings regarding the impact of racial diversity upon society, including that it lowers trust and erodes civic participation. ${ }^{118}$

115133 S. Ct. 2411 (2013).

${ }^{116}$ Brief of Abigail Thernstrom, Stephan Thernstrom, Althea K. Nagai, and Russell Nieli as Amici Curiae Supporting Petitioners, Fisher v. Univ. of Tex., 133 S. Ct. 2411 (2013) (No. 11-345).

${ }^{117} \mathrm{Id}$.

${ }^{118} \mathrm{Id}$. at 13 ("[P]eople of different racial and ethnic groups have a harder time getting along with one another-and trusting one another-than do people of the same race or same ethnic group. The more numerous the members of the outsider group present, and the more contact people have with them, the greater the level of inter-group distrust.”) (citations omitted); id. at 13 ("In racially and ethnically diverse communities, there is a decline in social solidarity, community activities, and general neighborliness as people tend to withdraw into themselves and become more isolated and alienated from others nearby. In Putnam's words, people under such circumstances 'hunker down' and 'pull in like a turtle.'”) (quoting Putnam, E Pluribus Unum, supra note 39, at 149). 
The Thernstrom brief motivated Putnam to submit his own brief in favor of the University of Texas. ${ }^{119}$ Putnam contends that the Thernstrom brief misuses his research by selectively quoting a few observations that support Fisher's position, while ignoring his conclusion that ethnic and racial diversity is inevitable and that it produces long-term benefits for society. ${ }^{120}$ Although Putnam does not specifically examine whether the suspect class doctrine causes racial friction, he endorses affirmative action policies, notwithstanding the fact that these policies treat whites and persons of color disparately and rest upon a recognition of group-based differences:

[P]olicies that seek a broad diversity, including racial and ethnic diversity, in educational institutions, such as those in use at UT, hold great promise in overcoming any potential short-run negative effects of diversity identified in the Thernstrom amici brief. A nation that is inevitably and increasingly diverse benefits from policies that promote social solidarity and trust through shared experiences and creation of a more inclusive social identity. ${ }^{121}$

In addition, Putnam has anticipated arguments that many progressives have made which link social capital with historical subordination. ${ }^{122}$ Tight, close-knit, homogeneous, and civically engaged communities helped to produce and sustain sexist, racist, xenophobic, classist, and sexually repressive policies. ${ }^{123}$ Conceding this reality, Putnam considers whether a necessary tension exists between social capital and equality. He forcefully rejects this position:

Does this logic mean that we must in some fundamental sense choose between community and equality? The empirical evidence on recent trends is unambiguous: No. Community and equality are mutually reinforcing, not mutually incompatible. Social capital and economic equality moved in tandem through most of the

${ }^{119}$ Brief for Robert D. Putnam as Amicus Curiae Supporting the University of Texas at 2, Fisher v. Univ. of Tex., 133 S. Ct. 2411 (2013) [hereinafter Putnam Brief] ("Dr. Putnam did not seek to become involved in this case, but because his findings on diversity were inaccurately and selectively described in the amicus curiae brief submitted by Abigail Thernstrom, Stephan Thernstrom, Althea K. Nagai, and Russell Nieli . . . he respectfully submits this brief to clarify the record.”).

${ }^{120} \mathrm{Id}$. at $4-5$.

${ }^{121} \mathrm{Id}$. at $21-22$.

${ }^{122}$ See PutNAM, Bowling Alone, supra note 98, at 358-59. See also infra text accompanying notes 168-79 (discussing role of social capital in fostering historical injustices).

${ }^{123}$ See infra text accompanying notes $168-79$. 
twentieth century. In terms of the distribution of wealth and income, America in the 1950s and 1960s was more egalitarian than it had been in more than a century. . . . [T] hose same decades were also the high point of social connectedness and civic engagement. Record highs in equality in social capital coincided. ${ }^{124}$

Although Putnam equivocates on the causal relationship between equality and social capital, he nonetheless does not believe that egalitarian claims defeat social capital or vice versa. ${ }^{125}$

Although the Supreme Court finds that affirmative action policies cause social division and balkanization, Putnam, one of the leading authors in the field of social capital, believes that promoting diversity and group interaction will actually lead to greater social solidarity and cohesion in the long-term and that "the race-conscious admissions policy that UT has implemented" will help facilitate the long-term management of racial difference. ${ }^{126}$ Putnam rejects the balkanization rhetoric as a reason for discarding group-based equal protection. He also disagrees with the idea that egalitarianism and social capital are incompatible. Thus, while some legal scholars and the Court have argued that race-conscious policies of inclusion cause social discord and divisions, Putnam argues that these practices have the opposite effect in the long-term and that they are necessary for an increasingly and inevitably pluralistic society.

\section{Putnam Has Retreated Somewhat from His Earlier Positions Regarding the Decline in Social Capital}

In addition to criticizing the use of his research to oppose affirmative action, Putnam has moderated some of his assertions regarding the decline in civic participation since the 1950s. For this additional reason, scholars should exercise caution before using Putnam's work to justify the Court's balkanization rhetoric.

On March 2, 2008, Putnam published an essay in The Boston Globe that examines the "rebirth of American civic life." ${ }^{27}$ Putnam argues that the 2008 Democratic presidential primaries and caucuses "have evinced the sharpest increase in civic engagement among American youth in at least a half-century, portending a remarkable revitalization of American

${ }^{124}$ Putnam, Bowling Alone, supra note 98, at 358-59 (emphasis in original).

${ }^{125}$ Id. at 359 (conceding difficulty establishing causality between social capital and equality); id. at 358-59 (rejecting idea that social capital and egalitarianism are mutually exclusive).

${ }^{126}$ Putnam Brief, supra note 119, at 3-4.

${ }^{127}$ Robert Putnam, The Rebirth of American Civil Life, THE BosTON GLOBE, Mar. 2, 2008, http://www.boston.com/bostonglobe/editorial_opinion/ oped/articles/2008/03/02/the_rebirth_of_american_civic_life/?page=full. 
democracy." "28 To support his contention, Putnam cites polling data of UCLA undergraduates that show an upswing in voting rates after years of continuous declines. ${ }^{129}$ Putnam attributes this rise in civic participation to the September 11, 2001 terrorist attacks. He argues that the tragedy had a unifying effect upon all Americans, reminding them that "we are all in this together." ${ }^{\prime 30}$ Putnam contends that the 2008 Democratic presidential primaries and caucuses mark the "coming-out" of a new politically engaged generation. ${ }^{131}$

Putnam made similar arguments regarding an increase in civic participation among younger voters in another 2008 article, Still Bowling Alone? The Post-9/11 Split. ${ }^{132}$ Putnam believes that other societal factors, such as the unifying effects of the September 11 terrorist attacks, social media, and Barack Obama's 2008 presidential campaign, have led to a revitalization of civic engagement. ${ }^{133}$ Thus, even if Putnam's observations that link ethnic and racial pluralism with social anxiety and division were correct, his later works suggest that these purported divisions have rapidly declined. Accordingly, his research and the writings of likeminded social capital theorists provide questionable support for the Supreme Court's balkanization rhetoric, its failure to validate the equal protection claims of vulnerable classes, and its hostile stance toward legislative remedies for discrimination and subordination.

\section{B. Social Capital Scholarship Has Received an Abundance of Academic Criticism}

Social capital literature, particularly Putnam's work, has generated an abundance of academic criticism. In fact, political scientist Carl Boggs made the observation regarding Bowling Alone that Putnam's "iconic status does not prevent his book from being so conceptually flawed and historically misleading that it would seem to require yet another large tome just to give adequate space to the needed systemic critique."134

Many authors agree with Boggs's observation; social scientists have published several books and numerous articles that contest various as-

$128 \mathrm{Id}$.

${ }^{129} \mathrm{Id}$.

${ }^{130} \mathrm{Id}$.

${ }^{131} \mathrm{Id}$.

132 Robert D. Putnam \& Thomas H. Sander, Still Bowling Alone? The Post 9/11 Split, 21 J. Democracy 9 (2010) [hereinafter Putnam \& Sander, Still Bowling Alone], available at http://www.hks.harvard.edu/ocpa/pdf/still\%20bow ling\%20alone.pdf.

${ }^{133} \mathrm{Id}$. at $10-13$.

${ }^{134}$ Carl Boggs, Social Capital and Political Fantasy: Robert Putnam's “Bowling Alone,” 30 THEORY \& SOC’Y 281, 282 (2001), available at http://www.jstor.org/stable/pdfplus/657878.pdf?acceptTC=true\&jpdConfirm=tr ue. 
pects of Putnam's work. ${ }^{135}$ These critiques question the methodology of social capital literature and the fundamental observations this scholarship makes regarding the divisiveness of racial and ethnic diversity. Many of the studies contest the finding that a strong negative relationship between racial and ethnic diversity and social cohesion even exists. To the extent that such a relationship exists, some critics argue that it is "weak and contingent on various individual and contextual factors."136

This section reviews some of the leading academic critiques of the argument that racial and ethnic diversity have diminished the level of civic participation in the United States and has led to a society of isolated individuals. This section does not provide an independent empirical assessment of Putnam's work. Instead, it relies upon reputable, persuasive, and voluminous empirical studies that question Putnam's findings. Given the numerous problems that social scientists have observed regarding Putnam's work, legal scholars should rethink using this research as a basis for explaining or justifying the Court's balkanization rhetoric and the abandonment of group-based equal protection.

\section{Causation Versus Correlation}

Many critics contend that Putnam's research does not permit a firm conclusion regarding causation and that he has only shown (if at all) correlation of social capital and a community's well-being. Princeton sociologists Alejandro Portes and Erik Vickstrom, for example, considered five variables that Putnam describes as "consequences of social capital: child welfare, single parenthood, economic inequality, poverty, and general population health." ${ }^{137}$ Because Putnam measures social capital levels

135 See Steven N. Durlauf, Bowling Alone: A Review Essay, 47 J. ECON. BEHAV. \& ORG. 259, 260 (2000) available at https://www.ssc.wisc.edu/econ/ archive/wp2029.pdf ("Bowling Alone is in many ways very disappointing, particularly when judged from the perspective of rigor or analytical depth. The many interesting facts that are documented are not subjected to a careful analysis of their causes or their consequences. Hence in my judgment, as a piece of scholarly social science, the book is largely a failure.”); Dietlind Stolle \& Marc Hooghe, Review Article: Inaccurate, Exceptional, One-Sided or Irrelevant? The Debate about the Alleged Decline of Social Capital and Civic Engagement in Western Societies, 35 BRIT. J. POL. SCI. 149, 150 (2004), available at http://prof s-polisci.mcgill.ca/stolle/Publications_files/FinalBJPS.pdf ("The Bowling Alone thesis has been variously characterized as plainly wrong, pessimistic or traditional. A number of authors have claimed that Putnam idolizes the vanished hierarchical world of the 1950s, in which most women were home-makers and therefore had more time on their hands to engage in various civic duties. Others depict the decline thesis as pure nostalgia, a manifestation of the longing for a civic and engaged era that has clearly ended.”).

${ }^{136}$ Alejandro Portes \& Eric Vickstrom, Diversity, Social Capital, and Cohesion, 37 ANN. REV. SOC. 461, 463 (2011), available at http://www.annual reviews.org/doi/pdf/10.1146/annurev-soc-081309-150022.

${ }^{137}$ Id. at 464. 
simultaneously with these five variables, determining causation becomes impossible. ${ }^{138}$

For example, Portes and Vickstrom question Putnam's findings that social capital reduces juvenile delinquency and arrests. While it is plausible that social capital leads to lower criminality and arrests among juveniles, it is also reasonable to assume that lower rates of criminality foster community trust and civic participation. ${ }^{139}$ Portes and Vickstrom make similar arguments regarding the other four factors they studied. Because Putnam does not use a "time sensitive measure" of the rates of social capital and the dependent variables he claims are causally related to social capital, his research can only prove correlation and not causation. ${ }^{140}$ Other scholars have made similar observations regarding social capital and its purported societal benefits. ${ }^{141}$

\section{Outmoded Measures of Civic Participation}

Scholars have also criticized Putnam's use of dated and outmoded measures of civic participation. For example, Putnam finds that declining membership in organizations such as the League of Women Voters, Elks Lodge, Moose Lounge, Knights of Columbus, Rotary Club, NAACP, and Parent-Teacher Association demonstrates a fall in social capital and civic participation. ${ }^{142}$ Putnam also asserts that religious participation, workplace connections, and informal social interactions foster greater social trust and higher levels of civic participation. ${ }^{143}$

Critics, however, argue that many of Putnam's measures of civic participation are relics of a bygone era and that they are not essential for social cohesion. Portes and Vickstrom, for example, assert that "[m]utual trust and bowling leagues are nice things to have, but they do not represent a sine qua nom for a viable society."144 Instead, "organic solidari-

${ }^{138} \mathrm{Id}$. at $464-65$.

$139 \mathrm{Id}$. at 464.

${ }^{140} \mathrm{Id}$. at $464-65$.

141 See, e.g., Steven Durlauf, supra note 135, at 262-64 (discussing causality flaws in Bowling Alone); Peter Nannestad, What Have We Learned About Generalized Trust, If Anything?, 11 ANN. REV. POL. SCI. 413, 429 (2008), available at http://www.annualreviews.org/doi/pdf/10.1146/annurev.polisci.11.06060 6.135412 ("Is growth the effect or one of the causes of generalized trust, or is there a two-way causation between generalized trust and growth/prosperity?”); Joel Sobel, Can We Trust Social Capital?, J. ECON. LIT. 139, 140 (2002), available at http://are.berkeley.edu/ cmantinori/prclass/Sobel.pdf ("[Bowling Alone] often confuses cause and effect. The argument of the book appears to be that measurable declines in group activities cause bad outcomes. With this interpretation, reductions in monetary donations to charity may be seen as a consequence of a decline in social capital . . . but not as direct proof that the stock of social capital has decreased.”).

142 Putnam, Bowling AlOnE, supra note 98, at 48-64.

143 Putnam, Bowling Alone, supra note 98, at 65-147.

${ }^{144}$ Portes \& Vickstrom, supra note 136, at 472 (emphasis in original). 
[Vol. 22:1

ty"-or agreement on a "set of norms that are understood and accepted by all and are enforced by specialized agencies"-can cohere diverse societies. ${ }^{145}$ "Mutual acquaintance" is not the exclusive route to social cohesion. ${ }^{146}$

In addition, the list of organizations that Putnam utilizes as indicators of civic engagement seems less relevant in a highly urbanized society with rapidly changing notions of gender and race and with increasing class disparity. ${ }^{147}$ Church attendance has fallen as public policy has relied more upon science and debate, rather than religious tenets. ${ }^{148}$ Many of the clubs that Putnam discusses, e.g., Rotary and Elks, are conformist and very traditional. Also, some forms of volunteerism declined because the organizations accomplished their short-term goals. ${ }^{149}$ Rather than indicating a decrease in social capital, declining membership in voluntary organizations could result from the changing needs of a larger segment of the population.

Putnam also discounts new forms of civic participation. Even if membership in large organizations such as the Rotary Club has fallen, Putnam does not consider alternative forms of participation that are less formal and that emerge to deal with specific issues. ${ }^{150}$ Furthermore, as several of his critics have observed, Putnam gives very little attention to the creation of new outlets for highly political and communitarian activities such as the Internet, social media, and social movements. ${ }^{151}$ In Bowling Alone, Putnam devotes only 33 out of 539 pages to examining these

${ }^{145} I d$. at 473.

${ }^{146}$ Id.

147 Boggs, supra note 134, at 284 (discussing Putnam's “arbitrary choice of indicators to reflect declining [social capital]”); Michael O’Connell, Anti 'Social Capital': Civic Values versus Economic Equality in the EU, 19 EURO. SoC. REV. 241, 242 (2003) ("It has been suggested that the data used by Putnam in his assessment of change in the USA may have masked the growth of new forms of social involvement, romanticized the quality and quantity of social involvement in the past, and ignored the change in organizational practices.”) (internal citations omitted).

148 See Boggs, supra note 134, at 284.

${ }^{149} \mathrm{Id}$. ("The older voluntary organizations Putnam cherishes went into decline precisely because they lost their raison d'etre as their goals became outmoded, mostly reflective of a small-town America that itself was in the process of vanishing.").

${ }^{150}$ C.S. Fisher, Bowling Alone: What's the Score?, 27 SOC. NETWORKS 155, 159 (2005) (discussing “ad hoc” volunteerism, such as “AIDS Walk, beach cleanup, or lobbying campaign”).

${ }^{151}$ See, e.g., Bob Edwards \& Michael W. Foley, Much Ado About Social Capital, 30 ConTEMP. Soc. 227, 238 (2001) (criticizing Putnam's dismissive analysis of social movements, new age churches, and workplace relationships); Fisher, supra note 150, at 159. 
alternative forms of volunteerism, political action, and communitarianism. ${ }^{152}$

\section{Ignoring Racial and Class Inequality}

Many scholars have criticized Putnam and other social capital theorists for their failure to account for racial and class inequality and segregation (among other factors) in their work. Some of these scholars find that racial and class disparities have a greater negative impact on social capital than racial and ethnic diversity. Others have argued that racial isolation and segregation matter more than racial and ethnic diversity. Some researchers have found that after controlling for racial and class inequality, racial diversity has a small or insignificant impact upon social capital. These findings, if accurate, seriously undermine the use of Putnam's work (and similar scholarship) to justify the Court's balkanization rhetoric and abandonment of class-based equal protection.

To test Putnam's conclusions, political scientist Eric Uslaner has conducted several empirical studies regarding social cohesion. Uslaner concludes that "[r]esidential segregation, not diversity, leads to lower levels of trust" and that "[s] egregation has been linked to a wide range of negative outcomes." 153 In his research, Uslaner studies the level of geographical racial isolation in several countries, including the United States. The countries in which minority racial groups experience the highest levels of isolation also have the "lowest levels of generalized trust," which social capital theorists treat as a precondition for civic participation. ${ }^{154}$

Putnam, by contrast, contends that diversity diminishes trust. ${ }^{155} \mathrm{Di}$ versity and racial isolation, however, are not mutually exclusive concepts. ${ }^{156}$ With respect to the United States, Uslaner finds that diversity diminishes trust primarily for whites, but not for African Americans (perhaps because trust levels among African Americans are typically low). ${ }^{157}$ On the other hand, integration and diversity increase trust sub-

152 See Putnam, Bowling Alone, supra note 98, at 148-89 (discussing possible bright spots in social capital, despite the overall decline).

153 Eric M. Uslaner, Segregation, Mistrust and Minorities, 10 ETHNICITIES 415, 416 (2010).

${ }^{154} \mathrm{Id}$.

155 See generally Putnam, E Pluribus Unum, supra note 39.

156 See Uslaner, supra note 153, at 424 ("Segregation and diversity are not the same thing.") (emphasis in original); id. ("High levels of diversity are compatible with perfect segregation, perfect integration, or anything in between.”).

${ }^{157}$ Id. at 426; see also RODNEY HERO, RACIAL DIVERSITY AND SOCIAL CAPITAL: EQUALITY AND COMMUNITY IN AMERICA (2007) (criticizing social capital theorists for not taking race into account and finding that racial diversity damages social capital among whites much more than among persons of color). 
stantially for both African Americans and whites, especially when these conditions lead to diverse friendship networks. ${ }^{158}$

In another publication, Bo Rothstein and Uslaner analyze the impact of economic inequality and inequality of opportunity upon social trust. ${ }^{159}$ Rothstein and Uslaner find that social trust levels are the highest in countries with greater economic equality. ${ }^{160}$ They also find a "powerful" negative relationship between trust and economic inequality in the United States using data from 1960 to 2002. ${ }^{161}$ Rothstein and Uslaner's research also finds that as economic inequality widens, trust levels decline. ${ }^{162}$ The authors do not claim that inequality alone influences the level of social trust in a country, but they do find that the relationship between the two variables is pervasive and strong. ${ }^{163}$

Numerous scholars have reached similar conclusions regarding the correlation between inequality and diminished social trust. Jong-sung You, for example, examines data from eighty countries, including the United States. ${ }^{164}$ Putnam's research and similar scholarship would predict that greater racial, ethnic, religious, and linguistic diversity negatively correlate with social trust. You, however, finds that only ethnic diversity correlates with a decline in social trust. ${ }^{165}$ After controlling for political corruption and income inequality, however, ethnic diversity has no significant effect upon social trust. ${ }^{166}$

158 Uslaner, supra note 153, at 424 (27\% for whites, 30\% for African Americans); see also id. ("Living in a city that is both diverse and integrated does not by itself increase trust. However, someone living in a city that is both diverse and integrated will be 27 percent more likely to trust others if (s)he has a diverse friendship network . ...”).

${ }^{159}$ Bo Rothstein \& Eric Uslaner, All for One: Equality, Corruption, and Social Trust, 58 WorLd POL. 41 (2005). (The authors also examine how political corruption impacts trust, but this topic is beyond the scope of this Article.).

${ }^{160}$ Id. at 47-48.

${ }^{161} \mathrm{Id}$. at 48.

${ }^{162} I d$. ("As we move from the low level of inequality in Belgium to the very high level in South Africa, trust declines by 23 percent.”).

${ }^{163}$ Id.

164 Jong-sung You, Social Trust: Fairness Matters More Than Homogeneity, 33 Pol. PsYCHOL. 701, 714 (2012).

${ }^{165} I d$.

${ }^{166}$ Id. See also Edward Fieldhouse \& David Cutts, Does Diversity Damage Social Capital? A Comparative Study of Neighbourhood Diversity and Social Capital in the US and Britain, 43 CAN. J. POL. SCI. 289, 307-08 (2010) (discussing the "crucial” impact of poverty on social capital in the US and concluding that the effect of poverty "outweigh[s] that of diversity by some distance"); id. (arguing that the impact of poverty on social capital is less in Britain than in the United States and hypothesizing that lower levels of minority concentrated poverty probably explains this result); Marc Hooghe, Tim Reeskens, Dietlind Stolle, \& Ann Trappers, Ethnic Diversity and Generalized Trust in Europe: A Cross-National Multilevel Study, CoMP. POL. SCI. 198, 211 (2009) ("Income inequality affects the level of the trust as expected: People are more trustful in 
This research challenges the connections that some social capital theorists have made between racial diversity and declining social capital. Social scientists have found that racial segregation and racial and economic class inequality have a greater negative effect upon (or negative correlation with) social capital than diversity alone. Although Putnam acknowledges the possibility that class stratification causes rather than results from diminished social capital, he fails to give economic inequality systematic treatment in Bowling Alone or E Pluribus Unum. ${ }^{167}$ In

countries with low levels of income disparity.”); James Laurence, The Effect of Ethnic Diversity and Community Disadvantage on Social Cohesion: A MultiLevel Analysis of Social Capital and Interethnic Relations in UK Communities, 27 EuRO. SOCIO. REv. 70, 85 (2011) ("Disadvantage . . . not only has a much stronger eroding effect on social capital than diversity, but is also associated with increasing intolerance. In fact, it is only when we control out disadvantage's negative effect that diversity significantly improves tolerance. Any truly concerted effort to tackle problems of community tensions must take this into account and not relegate the role of disadvantage at the expense of simply attempting to encourage greater community interaction.”); Natalia Letki, Does Diversity Erode Social Cohesion? Social Capital and Race in British Neighbourhoods, 56 POL. STUD. 99, 120 (2008) (finding a correlation between racial diversity and lower neighborhood trust, but nonetheless concluding that "when the association between racial diversity and economic deprivation is accounted for, there is no evidence for the eroding effect of racial diversity on interactions within local communities" and that "interactions improve perceptions of a neighbourhood, regardless of its economic status or racial composition, but these interactions are far less frequent in poorer neighbourhoods"); O'Connell, supra note 147 at 241-48 (arguing that economic equality is a much stronger predictor of social cohesion than social capital); Dan Rodríguez-García, Beyond Assimilation and Multiculturalism: A Critical Review of the Debate on Managing Diversity, J. INT'L MigRATION \& INTEGRATION 251, 268 (2010) (“[W]hen support for diversity occurs within a framework of social and political equality, and interaction across cultural difference becomes developed as a societal value ... the heterogeneous and dialogic civic space the occurs is more likely to have the effect of leading to overall greater social cohesiveness, rather than to outcomes of segregation and exclusion.”); see generally Portes \& Vickstrom, supra note 136, at 470 (reviewing literature linking racial segregation and economic inequality to a decline in social capital). At least one author, however, discounts any link economic inequality and social capital; instead, he argues that Putnam fails to consider the particular forms of social interaction that take place in poor communities of color. See James DeFillippis, The Myth of Social Capital in Community Development, 12 Housing POL'y DEBATE 781, 796-97 (2010) (discussing "trust-based relations" in "inner cities").

167 See PUTNAM, Bowling ALONE, supra note 98, at 359 (conceding that "great disparities of wealth and power are inimical to widespread participation and broadly shared integration" but declining to "adjudicate this complicated historical question”); Putnam, E Pluribus Unum, supra note 39, at 157 (observing that "people who live in neighbourhoods of greater economic inequality also tend to withdraw from social and civic life"). 
a more recent work, however, Putnam seems more convinced of the relevance of economic inequality to social capital. He warns that:

[T]he overall rise in youth political engagement and volunteering since $9 / 11$ masks a pair of subtrends that are headed in different directions, with lower-class youth growing less involved while better-off youngsters become more involved. Since public discussion in the United States often tends to conflate class and race, it is important to emphasize that this growing gap among different groups of young people is about the former and not just the latter.

If the United States is to avoid becoming two nations, it must find ways to expand the post-9/11 resurgence of civic and social engagement beyond the ranks of affluent young white people. The widening gaps that we are seeing in social capital, academic ambition, and self-esteem augur poorly for the life chances of working-class youngsters. If these gaps remain unaddressed, the United States could become less a land of opportunity than a caste society replete with the tightly limited social mobility and simmering resentments that such societies invariably feature. ${ }^{168}$

Putnam believes that social policy should address class inequality, but he fails to provide any specific vision regarding such remedies. Nonetheless, Putnam's recognition of the relationship between economic inequality and declining social capital seriously calls into question the use of his research to validate the Supreme Court's departure from group-based equal protection. If the Supreme Court truly believes that its doctrines should promote social cohesion, then it should vigorously utilize the Equal Protection Clause to help eradicate group-based inequities; these inequities cause more social division than diversity alone. The Court, however, has taken the exact opposite approach and interprets the Equal Protection Clause in a manner that sustains social disadvantages and privileges. ${ }^{169}$

\section{Negative Implications of Social Capital}

Social capital theorists have also received criticism because they treat the accumulation of social capital as inherently positive. This view, however, obscures the oppression and discrimination that civic participation and other forms of social capital can facilitate. Some social capital theorists distinguish "bonding" from "bridging" social capital. Bonding social capital describes civic engagement among small homogenous

\footnotetext{
${ }^{168}$ Putnam \& Sander, Still Bowling Alone, supra note 132 at 14.

${ }^{169}$ See infra text accompanying notes 227-67.
} 
groups, while bridging social capital refers to cohesion across a spectrum of different communities. ${ }^{170}$ Putnam argues that racial and ethnic diversity diminishes both types of group bonding. ${ }^{171}$ Putnam and other theorists, however, tend to dismiss the harmful societal consequences of social capital-particularly the historical injustices facilitated by political participation within homogenous communities.

Political scientist Barbara Arneil discusses the negative impact of bonding social capital in Diverse Communities, a comprehensive and methodical critique of Bowling Alone. ${ }^{172}$ As Arneil argues, Putnam describes the Progressive Era in glowing terms. ${ }^{173}$ Undoubtedly, earlytwentieth-century reformers pursued many laudable goals, including union organizing, social welfare, and expanded public education. These mass movements spurred by dynamic civic engagement also participated in and promoted some of the most oppressive practices and ideas in United States history, including eugenics, social Darwinism, xenophobia, forced assimilation, patriarchy, racism, forced sterilization, and sexual repression. ${ }^{174}$

\footnotetext{
170 PutNAM, Bowling Alone, supra note 98, at 22-23.

171 See Putnam, E Pluribus Unum, supra note 39, at 143-44.

172 See generally BARBARA ARNeIL, Diverse COMMUNITIES: THE PROBlem WITH SOCIAL CAPITAL (2006).

${ }^{173}$ Id. at 15 ("In the penultimate chapter of Bowling Alone, Robert Putnam makes the case that the Progressive Era, a society he considers to be replete with social capital, provides a largely positive model of social connectedness.”). Arneil provides a good description of the "Progressive Era": "The Progressive era dated from the end of the nineteenth century to around 1920 and was marked by a movement for social reform, particularly in urban centres, whereby community provision was made for the less well-off and immigrants . . a as well as by the larger political reforms of the Suffragette movement.” Id. at 15 n.1.

${ }^{174}$ See id. at 15-40 (discussing negative aspects of Progressive Movement); Irene Bloemraad, Compte Rendu: Diverse Communities, 33 CAN. J. SocIO. 439, 440 (2008) (review essay) ("The high point of social capital, which Putnam places in the Progressive Era, had a dark and oppressive side for women, ethnic and racial minorities, and those with disabilities. Civic unity, based on shared norms and a Christian vision of progress, meant forced assimilation for many immigrants and native Americans, exclusion of African Americans, forced sterilization of the disabled, and the assumption that women would work for the social capital of others and their community, but not their own empowerment.”); Pedro Cabán, Subjects and Immigrants During the Progressive Era, 23 DISCOURSE 26-31 (2001) (discussing racist and xenophobic roots of United States "Americanization" policies and how public schools became instruments of these policies); Catherine Cocks, Rethinking Sexuality in the Progressive Era, 5 J. GiLded Age \& THE PROgressive ERA 93 (2006) (discussing racist, sexist, and eugenics driven policing of sexuality during the Progressive Era); Gregory Michael Dorr, Defective or Disabled?: Race, Medicine, and Eugenics in Progressive Era Virginia and Alabama, 5 J. GILDED AGE \& PROGRESSIVE ERA 359 (2006) (discussing multiple dimensions of sexism, classism, racism, and eugenics that informed forced sterilization legislation); Eric L. Goldstein, The Unsta-
} 
The use of social capital among close-knit and homogenous groups also helped to sustain racial violence and exclusion. Legal scholar Stephanie M. Stern addresses this subject in The Dark Side of Town. ${ }^{175}$ Responding to the enthusiastic reception of social capital theories among property scholars, Stern argues that "sundown towns"-racially exclusionary early-twentieth-century locales policed by actual and threatened racial violence-existed because whites successfully utilized in-group bonding to maintain white supremacy:

In sundown towns, collective action was embedded in dense networks of social ties that spread information about riots, pledges, mob violence, and other coordinated action and channeled anti-black norms. Community cohesion helped to reward participants with social standing and group identity-benefits in addition to any implicit compensation they derived from racist acts. Groups of residents or business owners gathered to sign pledges not to employ blacks or to allow them to live in the area. Residents converged on blacks to warn them to leave town. ${ }^{176}$

Although Stern's work focuses exclusively on antiblack practices, Chinese Americans, Mexican Americans, and Native Americans experienced similar forms of racist mob violence, geographic exclusion, and dispossession. ${ }^{177}$

ble Other: Locating the Jew in Progressive-Era American Racial Discourse, 89 AM. JEWISH HIST. 383 (2001) (discussing negative portrayals of Jewish Americans during Progressive Era); Mara L. Keire, The Vice Trust: A Reinterpretation of the White Slavery Scare in the United States, 1907-1917, J. Soc. HIST. 5 (2001) (discussing use of intersecting corrupt businesses and white female sexual purity tropes by Progressive Era anti-vice movement); Thomas C. Leonard, Retrospectives: Eugenics and Economics in the Progressive Era, 19 J. ECON. PERSP. 207 (2007) (discussing the eugenics basis for labor and immigration reform during the Progressive Era); Sally M. Miller, For White Men Only: The Socialist Party of America and Issues of Gender, Ethnicity and Race, $2 \mathrm{~J}$. GILDED Age \& PROgRESSIVE ERA 283 (2003) (discussing racism, sexism, and Anglo-Saxon-centrism of the Socialist Party of America); Sarah Potter, "Undesirable Relations": Same-Sex Relationships and the Meaning of Sexual Desire at a Women's Reformatory during the Progressive Era, 30 FEMINIST STUDS. 394 (2004) (examining the racial, class, sex, and heterosexist dimensions of Progressive Era sexual moralists).

${ }^{175}$ Stephanie M. Stern, The Dark Side of Town: The Social Capital Revolution in Residential Property, 99 VA. L. REV. 811 (2013).

${ }^{176}$ Id. at 843. See also Durlauf, supra note 135, at 270 (arguing that "social capital, as understood by Putnam, was an important component in perpetuating racial isolation" in southern states).

177 D. Michael BotTOMS, AN ARISTOCRACY OF COLOR: RACE AND RECONSTRUCTION IN CALIFORNIA AND THE WEST, 1850-1890, at 169-201 
Historically, social capital enforced many of most pernicious aspects of racial subordination, including racial violence, economic deprivation, and segregation. Putnam, however, does not completely ignore these issues in his work. Indeed, he devotes a short chapter in Bowling Alone to discussing the risk that social capital can lead to harmful outcomes. ${ }^{178}$ Moreover, recognizing the terrible injustices of the Progressive Era does not require that scholars dismiss the entire time period or fail to consider whether it offers important lessons for political organizing. ${ }^{179}$ Nonetheless, the atrocities of this time period counsel against uncritical celebration and promotion of social capital. ${ }^{180}$

Due to the numerous problems that empirical scholars have found with Putnam's work and with similar scholarship, social capital theory does not serve as a firm basis for defending the Supreme Court's retreat from group-based equal protection, nor does it justify turning to dignitybased claims as a suitable replacement. Furthermore, as Part III demonstrates, social psychologists-who specialize in analyzing group-based behavior - offer research that provides a more helpful social context for understanding developments in the Court's racial discrimination doctrine. This research also offers empirical justifications for preserving group-based identities and equal protection.

(2013) (discussing violent removal of Chinese from areas of the West Coast during the nineteenth century); William D. CARrigan \& Clive WeBb, ForgotTen DeAd: Mob Violence Against Mexicans in the United STATES, 1848-1928, at 17-63 (2013) (discussing lynching of Mexicans in Southwest, due to racism, economic competition, and territorial clashes); Rennard Strickland \& William M. Strickland, Tale of Two Marshalls: Reflections on Indian Law and Policy, the Cherokee Cases, and the Cruel Irony of Supreme Court Victories, 47 OKLA. L. REV. 111 (1994) (discussing ejectment of Cherokee from Georgia).

${ }^{178}$ PutnAM, Bowling AlONE, supra note 98, at 350-63.

${ }^{179}$ See Robert D. Johnston, Re-Democratizing the Progressive Era: The Politics of Progressive Era Political Historiography, 1 J. GILDED AGE \& PROGRESSIVE ERA 68 (2002) (acknowledging the numerous injustices of the Progressive Era but arguing that the time period contains many positive lessons regarding political organizing). Problems regarding racial and class hierarchies existed within Progressive Era-movements for racial justice as well. See Susan D. Carle, Race, Class, and Legal Ethics in the Early NAACP (1910-1920), 20 L. \& HIST. REV. 97 (2002) (discussing how the control of the NAACP by white attorneys created conflict between the organization's goals and the opinions of most blacks).

${ }^{180}$ Many contemporary organizations also complicate the blanket assertion that social capital helps society. See Boggs, supra note 134, at 286 (discussing the "flourishing of small, local groups overflowing" with social capital such as "urban gangs, cults, paramilitary militias, and assorted patriarchal movements like Promise Keepers, Brotherhood of Aryan Nations, and the Muslim Brotherhood”). 


\section{PREVENTING BALKANIZATION OR FACILITATING RACIAL DOMINATION?}

The Supreme Court has interpreted the Equal Protection Clause as: (1) strongly prohibiting race-based legal remedies except in the narrowest circumstances; (2) generally permitting state action that negatively impacts historically disadvantaged classes; and (3) only barring discrimination against a few vulnerable classes, while leaving other groups to rely upon the political process for redress. The Court justifies these doctrinal choices on the grounds that to hold otherwise would lead to balkanization. According to the Court, recognition of group rights or remedies divides society. The budding dignity-based liberty doctrine, by contrast, arguably minimizes group conflict or pluralism anxiety because it identifies universal interests and does not require group identity as a basis for remediation. ${ }^{181}$

As an abstract principle, this analysis of Court doctrine seems unremarkable. Empirically, however, the balkanization rhetoric raises tremendous concerns regarding the Court's understanding of contemporary race relations, the institutional role of the Court, and the purpose of equal protection. As this Part demonstrates, the Court's discarding of the suspect class doctrine and the requirements of colorblindness and discriminatory intent does not avoid social conflict. Instead, the Court's interpretation of the Equal Protection Clause implements core beliefs that most whites hold regarding the status of race in the United States. Relative to persons of color, whites prefer colorblindness and oppose multiculturalism. Whites also tend to support individualism rather than group-based identity and rights. In addition, whites are more likely to believe that racism no longer represents a significant obstacle to equal opportunity. Finally, whites see themselves as a racially vulnerable class, perhaps even more susceptible of discrimination than persons of color. Most people of color strenuously disagree with these viewpoints. Accordingly, whether by design or effect, the Court's equal protection doctrine implements many of the core racial viewpoints held by whites and leads to the reinforcement of racial inequality. This is a peculiar form of equal protection.

\section{A. Social Psychology Theories of Group Behavior}

The traditional social capital literature, such as Putnam's research, offers a very limited understanding of group behavior. Other social science scholarship, however, provides greater insight regarding the motivation of individuals and groups. Specifically, works of social psychologists, who have analyzed the dynamics of group behavior for more than a century, provide more reliable and accurate material for understanding

${ }^{181}$ See Yoshino, The New Equal Protection, supra note 5. 
how the Court's equal protection doctrine relates to society. ${ }^{182}$ Prevailing themes in social psychology literature support the argument that the Court's justification for abandoning group-based equal protection mirrors the views that most whites have regarding race relations. These dominant-group views concerning race differ sharply from those of persons of color. Accordingly, social psychology literature helps demonstrate that the Court's equal protection doctrine is white-centric.

\section{Individualism Is a Social Construct}

Contrary to Court doctrine, social psychology literature does not view people as atomistic agents. Instead, the individual and society are mutually constitutive. Individuals define themselves within specific societal contexts; these individual personalities, in turn, help to shape the dynamics of larger group culture. ${ }^{183}$ Empirical research finds that this theory holds true even in societies like Western Europe and the United States with very strong cultures that emphasize individualism. ${ }^{184}$ While many legal doctrines treat the individual as the main object of civil rights law and a well-functioning society, social psychologists view the individual and society as inseparable:

[D]espite the ideology of individualism and the manifold political and legal practices that privilege the individual, people are not just autonomous individuals solely under their own production and orchestration. They are also centers of dynamic interpersonal relationships, and these relationships are significant in determining who they are, who they try to be, and how they behave. ... [I]ncreasingly it is evident that identity is indeed a group project. ${ }^{185}$

\section{Social Dominance Theory}

Social psychologists have also compiled substantial research regarding group-based inequality. In their influential book Social Dominance, psychologists Jim Sidanius and Felicia Pratto find that "all human socie-

182 See generally Dorwin Cartwright, 42 SoC. PSYCHOL. Q. 82 (1979) (observing in 1979 that the formal school of social psychology has existed for "approximately eighty years”).

${ }^{183}$ Hazel Rose Markus \& Shinobu Kitayama, Cultures and Selves: A Cycle of Mutual Constitution, 5 PsYCHOL. SCI. 420, 421 (2010).

${ }^{184}$ Hazel Rose Markus, Claude M. Steele \& Dorothy M. Steele, Colorblindness as a Barrier to Inclusion: Assimilation and Nonimmigrant Minorities, 129 DAEDALUS 233, 248 (2000).

${ }^{185} \mathrm{Id}$. Despite the prevalence of individualism discourse in equal protection case law, the Court has, in fact, recognized the important connections between the individual and society in several cases and doctrines. See infra text accompanying notes 305-12. 
ties tend to be structured as group-based social hierarchies." ${ }^{186}$ Diverging endowments of social value distinguish dominant and subordinate groups. ${ }^{187}$ Dominant groups possess a "disproportionately large share of positive social value" defined as "material and symbolic things for which people strive." 188 Subordinate groups, by contrast, "possess a disproportionately large share of negative social value." ${ }^{189}$ Items of positive social value include "political authority and power, good and plentiful food, splendid homes, the best available health care, wealth, and high social status." 190 Negative social value includes things such as "low power and social status, high-risk and low-status occupations, relatively poor health care, poor food, modest or miserable homes, and severe negative sanctions (e.g., prison and death sentences)." ${ }^{191}$ Sidanius and Pratto use the term "social dominance theory" to describe their conclusions regarding social organization. ${ }^{192}$

Sidanius and Pratto make two additional observations that shall inform this Article's ensuing discussion of Court doctrine. First, groupbased hierarchies are almost impervious to change. ${ }^{193}$ Even when egalitarian measures help to alleviate the conditions of subordinate groups, the relative inequality between subordinate and dominant classes remains the same. ${ }^{194}$ Second, group-based societies construct "legitimizing myths"-or "attitudes, values, beliefs, stereotypes, and ideologies that provide moral and intellectual justification" for group-based inequality. ${ }^{195}$

186 JiM SiDANIUS \& FELICIA PRATTO, SOCIAL DOMINANCE: AN INTERGROUP THEORY OF SOCIAL HIERARCHY AND OPPRESSION 31 (1999).

${ }^{187}$ Id. at 31-32.

${ }^{188} \mathrm{Id}$. at 31.

${ }^{189} \mathrm{Id}$. at 32.

${ }^{190}$ Id. at 31-32.

${ }^{191} \mathrm{Id}$. at 32. Sidanius and Pratto also distinguish group-based from individual-based social hierarchies. In a group-based hierarchy, individuals in dominant groups derive benefits from their membership in the dominant group; in individual-based hierarchy, benefits are earned by individual efforts. This distinction does not mean that dominant group members do not work to obtain positive value. Instead, the distinction emphasizes that individual differences cannot explain the disparity in positive social value held by dominant versus subordinate group members. Id. at 32.

192 Id. at 31.

193 Id. at 33-39.

${ }^{194}$ Id. at 37 (observing that the social status of blacks increased dramatically in public opinion polls between 1964 and 1989, but that the relative difference between white and black status remained virtually unchanged).

${ }^{195} \mathrm{Id}$. at 45. The concept of a legitimizing myth is similar to terms used by other social theorists to explain hierarchy-sustaining ideology. 


\section{B. Social Psychology Theory and Race Relations}

Researchers have conducted numerous empirical studies that test the claims made by Sidanius and Pratto. This research provides great insight into the dynamics of United States race relations and the impact of race upon Supreme Court doctrine, including equal protection case law. In particular, these studies reveal great disparities among the views of whites and persons of color regarding the desirability and appropriateness of multiculturalism and cultural pluralism versus colorblindness and assimilation; support for individualistic or group-based social models; contemporary relevance of race and racism to opportunities for social and economic advancement; and substantiality of racial discrimination against whites.

\section{Multiculturalism Versus Colorblindness}

Numerous studies have considered whether race impacts individual support for multiculturalism or colorblindness. The results of these studies are remarkably consistent and clear: generally, whites oppose multiculturalism and prefer colorblindness, while persons of color tend to support multiculturalism much more than colorblindness. ${ }^{196}$ The research

${ }^{196}$ See e.g., Evan P. Apfelbaum Samuel R. Sommers, \& Michael I. Norton, Seeing Race and Seeming Racist? Evaluating Strategic Colorblindness in Social Interaction, 95 J. PERSONALITY \& SOC. PSYCHOL. 918 (2008) (“Colorblindness has emerged as a norm endorsed by many Whites and evident across a wide range of domains . . . ."); Alison M. Konrad \& Frank Linehan, Race and Sex Differences in Line Managers' Reactions to Equal Employment Opportunity and Affirmative Action Interventions, 20 GRP. \& ORG. MGMT. 409, 424 (1995) (finding that persons of color and white women were more supportive of "identityconscious" hiring practices than white men and that persons of color were more supportive of such policies than white women); Markus et al., supra note 184, at 246 (discussing whites' preference for assimilation and colorblindness versus pluralistic perspective held by persons of color); Victoria C. Plaut Flannery G. Garnett, Laura E. Buffardi, \& Jeffrey Sanchez-Burks, "What About Me?”: Perceptions of Exclusion and Whites' Reaction to Multiculturalism, $101 \mathrm{~J}$. PERSONALITY \& SOC. PSYCHOL. 337, 339 (2011) (“Although there are certainly individual exceptions and wide variation, empirically, dominant racial/ethnic group members such as Whites appear to show less support for multiculturalism than do minorities.”); Aneeta Rattan \& Nalini Ambady, Diversity Ideologies and Intergroup Relations: An Examination of Colorblindness and Multiculturalism, EURO. J. OF SOC. PSYCHOL. 12, 13-14 (2013) ("The extant research shows that majority group members tend to endorse a colorblind ideology to a greater degree than minority group members. ...”); id. at 14 ("Minority group members are less likely to endorse colorblindness than are majority group members. Instead, they tend to endorse multiculturalism.”); Carey S. Ryan, Jennifer S. Hunt, Joshua A. Weibel, Charles R. Peterson, Juan F. Casas, Multicultural and Colorblind Ideology, Stereotypes, and Ethnocentrism among Black and White Americans, 10 GRP. PROCESSES INTERGROUP REL. 617, 623-24 (2007) (reporting results of a study finding that "the tendency to endorse multiculturalism more than 
makes this finding with such a high degree of certainty that it has become a standard working assumption among social psychologists. ${ }^{197}$

Researchers have isolated several factors that explain the differing views among whites and persons of color regarding colorblindness and multiculturalism. First, some researchers have found that whites believe multiculturalism does not include them. ${ }^{198}$ Others have observed that whites, particularly those who strongly support social dominance, oppose multiculturalism because they believe it threatens whites' higher social status. ${ }^{199}$ Some studies connect whites' opposition to multicultur-

colorblindness was greater among Black than White participants" and that "White participants more strongly endorsed a colorblind ideology than did Blacks" and that "Black participants more strongly endorsed a multicultural than a colorblind ideology”); Maykel Verkuyten, Ethnic Group Identification and Group Evaluation Among Minority and Majority Groups: Testing the Multiculturalism Hypothesis, J. PeRsonality \& SOC. PsychOL. 121, 134 (2005) (discussing results of a study in the Netherlands that finds greater support for multiculturalism among Turkish minority participants and more support for assimilation among Dutch majority participants); Maykel Verkuyten, Social Psychology and Multiculturalism, 1 SOC. \& PERSONALITY PSYCHOL. COMPASS 280, 283 (2007) [hereinafter Verkuyten, Social Psychology and Multiculturalism] ("Empirical studies on multicultural attitudes indicate that the general support for multiculturalism is not very strong among majority groups in many Western countries.”); Christopher Wolsko, Bernadette Park \& Charles M. Judd, Considering the Tower of Babel: Correlates of Assimilation and Multiculturalism among Ethnic Minority and Majority Groups in the United States, 19 Soc. JUST. RES. 277, 301 (2006) (reporting "clear patterns of divergence between the attitudes of whites and ethnic minorities," including greater support for multiculturalism and lesser support for assimilation among minority groups, relative to whites). One study makes a more tentative claim than others. See Jack Citrin, David O. Sears, Christopher Muste \& Cara Wong, Multiculturalism in American Public Opinion, 31 BRIT. J. POL. SCI. 247, 266 (2001) (“The tendency of minority groups to be more favourable towards multiculturalism than whites is present, but surprisingly modest.”).

${ }^{197}$ See sources cited supra note 196 (citing abundant scholarly support for the contention that whites favor colorblindness and assimilation more than persons of color and that persons of color prefer race-consciousness and multiculturalism more than whites).

198 Plaut et al., supra note 196, at 349 (finding that whites feel excluded from multiculturalism but not colorblindness); Rattan \& Ambady, supra note 196, at 14 (discussing whites' feelings of exclusion from multiculturalism).

${ }^{199}$ Lawrence Bobo, Race, Interests, and Beliefs About Affirmative Action, 41 AM. BeHAV. SCIENTIST 985, 997 (1998) (finding that "group-based interests" explain, in part, white opposition to affirmative action); Christopher M. Federico \& Jim Sidanius, Racism, Ideology, and Affirmative Action Revisited: The Antecedents and Consequences of "Principled Objections" to Affirmative Action, 82 J. PERSONALITY \& SOC. PSYCHOL. 488, 499 (2002) (finding that support for group dominance among whites explains white opposition to affirmative action directly and indirectly-by influencing whether whites accept purportedly principled policy arguments used to oppose affirmative action); Brian S. 
alism and support for colorblindness to their ideological and political views regarding policies such as affirmative action. ${ }^{200}$ These studies, in turn, find that a number of variables correlate with or cause white opposition to affirmative action, including racism, principled policy arguments, and the framing of the policy in public discourse (e.g., as a quota or preference versus training and outreach). ${ }^{201}$

\section{Groups Versus Individuals}

Whites also tend to have a social orientation that denies group differences and stresses individualism, while persons of color support policies that emphasize group differences and experiences. ${ }^{202}$ This conclusion relates to race-based differences regarding the attractiveness of multiculturalism or colorblindness. Colorblindness, which whites prefer more than persons of color, treats "group differences" as "largely superficial" or "not substantial enough to warrant a claim on public policy or social organization." 203 People of color, by contrast, are more likely to support multiculturalism, which "holds that ethnic and racial variety is pleasing and important, both to the various groups themselves and to society as a whole-so important, in fact, that it can and should be celebrated."204

\section{Contemporary Relevance of Racism}

Statistical studies consistently find vast disparities among the social and economic well-being of whites and persons of color. ${ }^{205}$ Despite the pervasiveness of substantive racial inequality, whites tend to believe that

Lowery, Mighuel M. Unzueta, Eric D. Knowles \& Phillip Atiba Goff, Concern for the In-Group and Opposition to Affirmative Action, 90 J. PERSONALITY \& Soc. Psychol. 961, 970 (finding that white opposition to affirmative action increases if they believe it threatens their group status); C. Lausanne Renfro, Walter G. Stephan, Anne Duran \& Dennis L. Clason, The Role of Threat in Attitudes Toward Affirmative Action and Its Beneficiaries, 36 J. ApP. Soc. PsYchOL. 41, 68 (2006) (finding higher opposition to affirmative action among whites who believe that such policies threaten their economic and political power, among other things); Verkuyten, Social Psychology and Multiculturalism, supra note 196, at 284 (arguing that some whites believe that multiculturalism threatens their group's dominance).

${ }^{200}$ Hillary Haley \& Jim Sidanius, The Positive and Negative Framing of Affirmative Action: A Group Dominance Perspective, 10 PersonAliTy \& SoC. PSYCHOL. BULL. 656, 666 (2006) (discussing framing effects); Renfro et al., supra note 199, at 69 (discussing relevance of racism and conservative ideology).

${ }^{201}$ See sources cited supra note 200.

${ }^{202}$ Markus et al., supra note 184, at 243-49.

${ }^{203} \mathrm{Id}$. at 243.

${ }^{204} \mathrm{Id}$. at 244. See also id. at 246 (discussing surveys showing racial differences in support for colorblindness and multiculturalism).

${ }^{205}$ Id. at 242. 
equal opportunity exists in the United States regardless of race; people of color, however, typically disagree with this position. ${ }^{206}$ Whites' propensity to believe that racism no longer matters could operate as a legitimizing myth, designed to validate the unequal distribution of power and resources among persons of color and whites. ${ }^{207}$ If racism no longer exists, then any measurable inequality does not result from unfairness, which might require legislative and judicial remediation. Instead, individual weaknesses among persons of color or other nonracial variables must explain contemporary racial inequality. From this perspective, remediation is a privilege or special benefit.

Denying the existence of racism could also stem from a psychological mechanism described as "system justification." ${ }^{208}$ System justification refers to "the psychological process by which existing social arrangements are legitimized, even at the expense of personal and group interest." 209 If individuals convince themselves that existing social arrangements are just, then they will find no need for remedial policies. ${ }^{210}$

${ }^{206}$ Elijah Anderson, Duke W. Austin, Craig Lapriece Holloway \& Vani S. Kulkarni, The Legacy of Racial Caste: An Exploratory Ethnography, 642 ANNAlS AM. ACAD. POL. \& SOC. SCI. 25, 37 (2012) (summarizing different views whites and blacks hold with respect to the contemporary significance of racism); Richard P. Eibach \& Thomas Keegan, Free at Last? Social Dominance, Loss Aversion, and White and Black Americans' Differing Assessments of Racial Progress, 90 J. Personality \& Soc. Psychol. 453, 453 (discussing opinion polls showing dramatic difference between black and white opinions regarding the existence of racial discrimination); Darren Lenard Hutchinson, Racial Exhaustion, 86 WASH. U. L. REV. 918, 919 n.4 (2009) [hereinafter Hutchinson, Racial Exhaustion] (citing numerous studies finding dramatic differences among whites and persons of color regarding the ongoing significance of race).

${ }^{207}$ See Roger L. Worthington, Michael Loewy, Rachel L. Navarro \& Jeni Hart, Color-Blind Racial Attitudes, Social Dominance Orientation, RacialEthnic Group Membership and College Students' Perceptions of Campus Climate, 1 J. Div. HigHER EDUC. 8, 16 (2008) (finding that white students who support social dominance have a more positive perception of "general campus climate" than egalitarian whites).

${ }^{208}$ John T. Jost \& Mahzarin R. Banaji, The Role of Stereotyping in SystemJustification and the Production of False Consciousness, 33 BRIT. J. SOC. PsYCHOL. 1, 2 (1994).

${ }^{209}$ Id. at 2. See also Cheryl J. Wakslak, John T. Jost, Tom R. Tyler \& Emmeline S. Chen, Moral Outrage Mediates the Dampening Effect of System Justification on Support for Redistributive Social Policies, 18 PsychOL. SCI. 267, 267 (2007) ("According to system-justification theory, people adopt ideologies and belief systems that serve as excuses and justifications for existing social, economic, and political arrangements at least in part to make themselves feel better about the status quo.") (citation omitted).

${ }^{210}$ See Wakslak, supra note 209, at 273 ("We assume that people care about justice, at least to some degree, and are bothered by potential departures from fairness. In order to maintain their perceptions of the world as just, however, people do not necessarily strive to make changes that will increase the overall 
In fact, they might even believe that remedial action is unfair. ${ }^{211}$ System justification, however, does not rest upon a desire for group dominance. Instead, it reflects a human need to believe that the society in which one lives operates fairly. ${ }^{212}$

\section{Whites Are a Vulnerable Social Group}

Within the United States, whites began criticizing policies taken to ameliorate the conditions of racial inequality immediately after the Civil War and throughout the period of Reconstruction. ${ }^{213}$ Opponents of remedial policies and civil rights statutes argued that these efforts treated whites unfairly and transformed blacks into a special and privileged class. ${ }^{214}$ This rhetoric of "racial exhaustion"-whites' weariness with racial redress-has continued over the course of American history. ${ }^{215}$ Whites who opposed the Civil Rights Act of 1964 argued that it would force employers to utilize quotas and that it would deprive whites of liberty. ${ }^{216}$ Also, whites have frequently contested affirmative action on the grounds that it constitutes unfair discrimination against whites. ${ }^{217}$

Although the idea that remedying racial discrimination harms whites has informed civil rights debates throughout history, recent studies indicate that whites now feel that they are just as vulnerable to racism as persons of color-or even to a greater extent. In 2011, Michael Norton and Samuel Sommers published a study that found that whites believe they are a vulnerable racial group. ${ }^{218}$ Norton and Sommers polled a national sample of blacks and whites and asked them to rate on a scale of one to ten (one representing "not at all” and ten representing "very much") the amount of discrimination they believe blacks and whites experienced in each decade from the 1950s to the 2000s. ${ }^{219}$

amount of fairness and equality in the system. Rather, they often engage in cognitive adjustments that preserve a distorted image of reality in which the world is a fair and just place.").

${ }^{211}$ Michael I. Norton \& Samuel R. Sommers, Whites See Racism as a ZeroSum Game That They Are Now Losing, 6 PERSP. PSYCHOL. SCI. 215, 217 (2011) (finding that from 1950s to 2000s and within each decade during this period, "White respondents were more likely to see decreases in bias against Blacks as related to increases in bias against Whites-consistent with a zero sum view of racism among Whites-whereas Blacks were less likely to see the two as linked.”).

${ }^{212}$ Wakslak, supra note 209, at 273.

${ }^{213}$ Hutchinson, Racial Exhaustion, supra note 206, at 928-41.

${ }^{214}$ See id.

215 See generally id.

${ }^{216}$ See id. at 950-53.

${ }^{217} \mathrm{Id}$. at $953-58$.

${ }^{218}$ Norton \& Sommers, supra note 211.

${ }^{219}$ Id. at 216. 
[Vol. 22:1

The study found that blacks believe antiblack racism has declined slightly over time. ${ }^{220}$ Blacks, however, do not believe that whites have experienced racism to a substantial degree; this position remained virtually unchanged in each rated decade. ${ }^{221}$ Whites, by contrast, believe that antiblack racism has declined sharply, while antiwhite racism has increased dramatically - particularly since the 1970s. ${ }^{222}$ The study controlled for the age and education of participants, but it found no statistically significant changes in the results. ${ }^{223}$ Also, the study found that black and white assessments of antiblack and antiwhite racism were quite similar for earlier decades, but that the measures diverged dramatically from the 1960s and beyond. ${ }^{224}$ A majority of white participants believe that by the 2000s, antiwhite racism became more prevalent than antiblack racism. ${ }^{225}$

Norton and Sommers also found that whites who believe that they are members of a vulnerable social group are more likely to view racial equality gains as unfair benefits earned at their expense. ${ }^{226}$ In other words, many whites view racism as a zero-sum game; changing the status quo of racial inequality can only occur by treating whites unfairly. ${ }^{227}$

\section{The Supreme Court's Equal Protection Doctrine Mirrors White Viewpoints Regarding Race}

The analysis in the preceding section demonstrates that as a class, whites tend to favor colorblindness over multiculturalism, embrace individualistic rather than group-based models of social organization, believe that equal opportunity exists in the United States regardless of race, and feel that they are a vulnerable racial group. This section demonstrates that the Supreme Court's equal protection doctrine mirrors white opinion regarding the status of race relations in the United States. Because this Article has already analyzed the Court's equal protection doctrine in extended detail, demonstrating the congruence of white viewpoints and Court doctrine does not require a lengthy analysis. The similarities are striking.

\footnotetext{
${ }^{220} I d$.

${ }^{221} I d$.

${ }^{222} I d$.

${ }^{223} \mathrm{Id}$.

${ }^{224} \mathrm{Id}$.

${ }^{225} \mathrm{Id}$.

${ }^{226}$ Id. at 217.

${ }^{227}$ Id.; see also Eibach \& Keegan, supra note 206, at 464 ("Cumulatively, these studies support the argument that the discrepancy between White and nonWhite assessments of racial progress results, in part, from the tendency of some White Americans to frame advances for racial minorities as threats to their own status and privilege or, in other words, to their ingroup's social dominance.”).
} 
1. Multiculturalism Versus Colorblindness

The Court, like whites, prefers colorblindness to multiculturalism and race-conscious decision making. Colorblindness is, in fact, the central standard the Court applies in equal protection cases. ${ }^{228}$ The Court has refused to apply other theories, such as antisubordination, that legal scholars have developed. ${ }^{229}$ The Court has never confronted the reality that its discussion of social tension within the context of affirmative action and other forms of remedial race-conscious state action responds primarily to whites' opinions regarding these policies. ${ }^{230}$

\section{Groups Versus Individuals}

The Court, like whites, rejects group-based social models. The Court has repeatedly held that the Constitution protects individual, rather than group, rights. The Court has also held that recognition of racial groups disrupts social cohesion. Consequently, the Court views group-based remediation, such as affirmative action, with extreme skepticism. ${ }^{231}$ The Court's aversion to group-based equal protection also explains its failure to recognize a new suspect class since $1977 .{ }^{232}$

\section{Contemporary Relevance of Racism}

Although the Supreme Court has never said that racism no longer exists, several opinions rest on the implicit understanding that the United States is a post-racial society. First, the Court has made remedying racial discrimination the most difficult basis for using affirmative action. When state actors make racial distinctions in order to remedy discrimination, the Court demands exacting evidence of disparate treatment. Otherwise, the policy will fail the strict scrutiny test. ${ }^{233}$ In Adarand Constructors $v$. Peña, the Court held that a federal statute's rebuttable presumption that minority businesses face social disadvantages must satisfy the strict scrutiny test. ${ }^{234}$ The Court's ruling implies that discrimination against racial

228 See supra text accompanying notes 41-56.

${ }^{229}$ See infra text accompanying notes 327-30.

230 See S. Siegel, Race-Conscious Student Assignment Plans, supra note 5 ("Another difficulty is that the same use of racial criteria may cause race-based hostility to increase among members of one racial group and to decrease among members of another racial group. For example, an affirmative action program may cause more resentment among some whites but less resentment among some minorities than would exist in the absence of the program. No decision rule is available to explain how the Court's judgment about balkanization proceeds in these circumstances.”).

231 See supra text accompanying notes 41-56.

232 See Yoshino, The New Equal Protection, supra note 5, at 755.

233 See Hutchinson, Inversion of Privilege and Subordination, supra note 3, at 675-77 (discussing the Court's distrust of legislative findings of discrimination).

234 See 515 U.S. 200, 200 (1995). 
minorities occurs rarely, if at all, and that individual businesses must demonstrate on a case-by-case basis the relevance of race to economic activity. ${ }^{235}$

Similarly, in Parents Involved, a plurality of the Court found that the racial isolation of people of color in public schools does not justify racebased remedies. The Court reached this conclusion by narrowly defining discrimination in procedural terms. Conditions of racial inequalityeven if they result from state policies-simply do not constitute racial discrimination. According to the plurality, the only discrimination the case implicated was the defendants' efforts to create a more egalitarian distribution of education resources. Thus, Chief Justice Roberts chides the dissenters by reminding them that " $[t]$ he way to stop discrimination on the basis of race is to stop discriminating on the basis of race." ${ }^{236}$ This sterile tautology validates pervasive patterns of inequality that negatively impact students of color. On the other hand, race-remedial policies receive the most rigorous judicial scrutiny to make sure that the state actors do not victimize whites.

In a concurring opinion, Justice Kennedy sought to distance himself from the conservative plurality. Kennedy argued that states have a compelling interest to end the racial isolation of students of color. ${ }^{237}$ Kennedy, however, voted to invalidate the policies due to the dignity harms they imposed upon white students. ${ }^{238}$ Kennedy did not sufficiently consider the significance of the alleged dignity harms whites suffer from racial classification versus the concrete material harms that students of color experience because they attend racially isolated poverty schools. ${ }^{239}$ Although Kennedy tried to carve out a middle ground, his resolution placed the interests of whites above the needs of students of color.

The Court has even advanced the interest of states' "dignity" above the needs of persons of color. In Shelby County v. Holder, the Supreme Court invalidated the preclearance requirements contained in Section 5 of the Voting Rights Act. ${ }^{240}$ The preclearance provision mandated that

235 See Spann, supra note 23, at 52 ("The reason that the Supreme Court rejected the congressional presumption is that the Court has adopted a theoretical vision of the world, where racial minorities are not disadvantaged.”).

${ }^{236}$ Parents Involved in Cmty. Sch. v. Seattle Sch. Dist. No. 1, 551 U.S. 701, 748 (2007).

${ }^{237} \mathrm{Id}$. at 783 .

${ }^{238} \mathrm{Id}$. at 797 ("To be forced to live under a state-mandated racial label is inconsistent with the dignity of individuals in our society.”).

${ }^{239}$ See generally Gary Orfield and Chungmei Lee, Why Segregation Matters: Poverty and Educational Inequality, THE CIV. RighTS PROJECT, HARVARD UNIV.(2005), http://civilrightsproject.ucla.edu/research/k-12-education/integrati on-and-diversity/why-segregation-matters-poverty-and-educational-inequality/o rfield-why-segregation-matters-2005.pdf (discussing the negative educational impact of poverty and racial isolation).

240133 S. Ct. 2612 (2013) (finding current standards for 42 U.S.C. §1973(a) to be an impermissible intrusion upon state sovereign immunity). 
certain states and jurisdictions within other states receive approval from the U.S. Department of Justice before they made any changes to their election laws. ${ }^{241}$ Congress enacted this provision because these jurisdictions were among the worst offenders of the Fifteenth Amendment at the time the Voting Rights Act was enacted. ${ }^{242}$ Congress renewed the Voting Rights Act in 2006. ${ }^{243}$ At that time, several lawmakers and public commentators questioned the usefulness of Section 5, arguing that the covered states no longer discriminated on the basis of race. ${ }^{244}$ Perennial civil rights opponents Abigail Thernstrom and Edward Blum offered a perspective that Justice Scalia would later repeat during oral arguments seven years later, when they effectively described Section 5 as a handout to a special interest group. Thernstrom and Blum pleaded with Congress not to surrender to "Jesse Jackson and other activists eager to wave the racism flag" and that congressional Republicans are "terrified by . . . the NAACP, the Lawyers Committee on Civil Rights, and other advocacy groups." ${ }^{245}$ During oral arguments, Justice Scalia, following the lead of Thernstrom and Blum, infamously described the preclearance provision as a "racial entitlement," rather than a sorely needed measure to prevent ongoing racial discrimination. ${ }^{246}$ Because Justice Scalia either doubts or does not care that race continues to harm persons of color, he construes Section 5 as a naked racial privilege that injures states rather than offering necessary protection to vulnerable classes. ${ }^{247}$

The Shelby County opinion makes similar claims about the irrelevance of race. Justice Roberts, who also wrote the plurality opinion in Parents Involved, argued that the Voting Rights Act "imposes current

${ }^{241} I d$. at 2615.

${ }^{242}$ Christopher S. Elmendorf, Making Sense of Section 2: Of Biased Votes, Unconstitutional Elections, and Common Law Statutes, 160 U. PA. L. REV. 377, 383 (2012) ("Section 5, the VRA's other core provision, reaches only 'covered jurisdictions' (states and some localities that once had particularly egregious records of voting discrimination) and guards primarily against backsliding." (citation omitted)).

243 Abigail Thernstrom, Redistricting in Today's Shifting Racial Landscape, 23 STAN. L. \& POL’y REV. 373, 393 (“In 2006 Congress once again substantially rewrote section 5. .).

244 See Hutchinson, Racial Exhaustion, supra note 206; infra text accompanying notes 298-311.

${ }^{245}$ Hutchinson, Racial Exhaustion, supra note 206 (quoting Abigail Thernstrom \& Edward Blum, Do the Right Thing, WALL ST. J., July 15, 2005, at A10).

${ }^{246}$ Adam Liptak, Voting Rights Law Draws Skepticism From Justices, N.Y. TIMES, Feb. 27, 2013 ("Justice Antonin Scalia said the law, once a civil rights landmark, now amounted to a 'perpetuation of racial entitlement."”).

247 Shelby County v. Holder, 133 S. Ct. 2612 (2013) (invoking a principle of "a union of States, equal in power, dignity and authority" as controlling precedent (citing Coyle v. Smith, 221 U. S. 559, 567 (1911)). 
[Vol. 22:1

burdens and must be justified by current needs." ${ }^{248}$ Echoing the sentiments of white participants in a recent study regarding the status of United States race relations from the 1950s until the present, Chief Justice Roberts wrote that "things have changed dramatically" since the enactment of the Voting Rights Act in $1965 .{ }^{249}$ The contention of dramatic racial progress, however, reflects majoritarian views held by whites-not persons of color. ${ }^{250}$

The Court also held that because voter turnout in the covered states has increased substantially, the preclearance formula needs revision. ${ }^{251}$ The Court, however, fails to consider the numerous laws that primarily Republican-controlled states, including some subject to preclearance, have enacted to deprive people of color of the right to vote. These policies include voter ID laws, permissive use of poll watchers who can intimidate persons of color and language minorities, the use of purging lists that disparately impact persons of color, and felon disenfranchisement. ${ }^{252}$ Immediately after the Court enjoined the preclearance provision, several Republican-controlled state legislatures introduced bills that would enact new provisions that scholars believe could disparately impact persons of color. ${ }^{253}$ While the Court portrays Section 5 as outmoded because of dramatic improvement in race-relations, the legislative blitz following the Shelby County decision undermines the Court's forgiving analysis of contemporary racism.

If racism was actually negligible in contemporary America, then Shelby County would arguably contain a defensible doctrine. However, because racism remains pervasive in the United States, Shelby County rests on a fictitious vision of contemporary United States race relations. The case also mirrors the views held by most whites today: racism is a

${ }^{248}$ Id. (quoting Northwest Austin Municipal Util. Dist. No. One v. Holder, 557 U.S. 193, 203 (2009)).

${ }^{249} \mathrm{Id}$.

${ }^{250}$ Supra text accompanying notes 205-12.

${ }^{251}$ Shelby County, 133 S. Ct. 2612 ("In the covered jurisdictions, '[v]oter turnout and registration rates now approach parity. Blatantly discriminatory evasions of federal decrees are rare. And minority candidates hold office at unprecedented levels."” (quoting Northwest Austin, 557 U.S. at 202)).

252 Jesse Allen, Documentary Disenfranchisement, 86 TUL. L. REv. 389 (2011) (discussing methods of felon disenfranchisement); Jocelyn Friedrichs Benson, Voter Fraud or Voter Defrauded? Highlighting an Inconsistent Consideration of Election Fraud, 44 HARV. C.R.-C.L. L. REV. 1 (2009) (discussing voter purge lists); Gilda Daniels, Voter Deception, 43 IND. L. REV. 343 (2010) (discussing forms of voter harassment); Daniel Tokaji, The New Vote Denial: Where Election Reform Meets the Voting Rights Act, 57 S.C. L. REV. 689 (2006) (discussing methods of vote denial).

${ }^{253}$ Michael Cooper, After Ruling, States Rush to Enact Voting Laws, N.Y. TIMES, July 5, 2013, http://www.nytimes.com/2013/07/06/us/politics/afterSupreme-Court-ruling-states-rush-to-enact-voting-laws.html?pagewanted=all\&_ $\mathrm{r}=0$. 
thing of the past, and the nation has virtually ended all racism through the extension of civil rights to people of color. ${ }^{254}$ In a post-racial society, civil rights enforcement and remedies are unnecessary and should be rare, narrow, and discrete.

\section{Whites Are a Vulnerable Social Group}

The Court also treats whites as a vulnerable social group. Although persuasive arguments justify applying a more lenient standard to evaluate the constitutionality of remedial state action that treats whites differently than persons of color, the Court applies strict scrutiny to such policies. At the same time, however, the Court applies ordinary rational basis review to state action that disparately harms disadvantaged groups, including when these policies occur in policy areas such as education and criminal justice that served as historical sites of pernicious racial subordination. ${ }^{255}$

Furthermore, while the Court imposes an exacting intent standard upon historically disadvantaged plaintiffs, it has shown a greater willingness to find unlawful discrimination in cases brought by white plaintiffs. ${ }^{256}$ In Ricci v. DeStefano, the Court held that a municipal government's decision to cancel the use of a test used to screen applicants for a promotion in the city's fire department violated Title VII of the Civil Rights Act of $1964 .{ }^{257}$ Even though the test results would have excluded all black candidates and all but two Latino candidates from the field of qualified individuals, the Court held that scrapping the test would discriminate against whites. ${ }^{258}$

Title VII, however, contains an impact standard, and the city argued that using the test might make the city susceptible to lawsuits. ${ }^{259}$ The Court, however, held that the city needed a "strong basis in evidence" for believing that using the test would make it vulnerable to lawsuits filed by persons of color, that it could replace the initial test with one that had a smaller discriminatory impact, and that the initial test was not a valid

254 Supra text accompanying notes 204-212.

${ }^{255}$ Hutchinson, Inversion of Privilege and Subordination, supra note 3, at 664.

${ }^{256}$ Reva Siegel, Equality Divided, 127 HARV. L. REV. 1, 51-58 (2013) [hereinafter R. Siegel, Equality Divided] (discussing inconsistent application of the discriminatory intent requirement).

257557 U.S. 557 (2009) (finding violation of 42 U.S.C. § 2000e2(k)(1)(A)(i) (2009)). Although Ricci is a Title VII case, rather than an equal protection case, the Court finds intentional discrimination (which is the equal protection standard), and the defendant is a state actor. Also, the Court analogizes this case to equal protection litigation. Thus, it fits within the general scope of this Article. See also Ricci, 557 U.S. at 582-93.

${ }^{258} \mathrm{Id}$.

${ }^{259}$ Id. at 563-74 (discussing test and city’s decision to discard the results). 
job requirement. ${ }^{260}$ The extreme disparate effect and the various meetings and legal discussions the city held concerning the test failed to meet that standard. ${ }^{261}$ The white plaintiffs, however, prevailed on their claim of intentional discrimination, despite the fact that hiring and promotion criteria that disparately impact racial groups, absent some legitimate reason, can constitute unlawful discrimination under federal law. ${ }^{262}$ Furthermore, the white plaintiffs proved intentional discrimination by relying primarily upon the same statistical pattern of discrimination that the city used to justify discarding the test. ${ }^{263}$ The Court chose to extend greater protection to the white victims of alleged discrimination than it provided to the black and Latino employees the city tried to shield from the test's discriminatory impact. The Court also provided more protection to white plaintiffs than it typically extends to persons of color litigating mere impact claims. ${ }^{264}$ The Court found intentional discrimination relying almost exclusively on statistical evidence. This is a great departure from the normal discriminatory intent rule cases. In most discriminatory intent rule cases, the plaintiffs are persons of color; in Ricci, virtually all of the plaintiffs were white.

The discriminatory intent rule, the Court's application of strict scrutiny to remedial usages of race, and its refusal to find any new suspect classes, support the observation that the Court has "inverted" the meaning of equal protection. ${ }^{265}$ The Court now extends greater protection to privileged classes, such as whites, than it provides to vulnerable classes, such as persons of color. ${ }^{266}$ Or, as Siegel contends, the Court's equal protection doctrine has become "majority-protective."267

Even assuming that the Court should use a uniform standard for all racial discrimination claims, the Court has not defended why it should provide greater protection to whites than it gives to persons of color.

${ }^{260} I d$. at $582-94$.

${ }^{261} I d$.

${ }^{262}$ Id. at 581-85 (conceding disparate impact liability under Title VII but requiring very high burden on city to establish a strong basis that the lawsuit would be compelling).

${ }^{263} \mathrm{Id}$. at 579 ("All the evidence demonstrates that the City chose not to certify the examination results because of the statistical disparity based on racei.e., how minority candidates had performed when compared to white candidates.”) (emphasis added).

${ }^{264}$ See supra text accompanying notes 256-58.

265 See Hutchinson, Inversion of Privilege and Subordination, supra note 3 (arguing that the Court has inverted the concepts of privilege and subordination and that it provides the greatest judicial protection for dominant classes and sends subordinate groups to the political process); see also R. Siegel, Equality Divided, supra note 256, at 29-59 (discussing “majority-protective" equal protection).

266 See Hutchinson, Inversion of Privilege and Subordination, supra note 3.

267 Siegel, Equal Divided, supra note 256, at 29-58 (discussing “majorityprotective” equal protection). 
Although no statistical measure of social and economic well-being supports the argument that whites suffer from racial oppression, a recent study shows that whites now believe that they experience discrimination more frequently than blacks. ${ }^{268}$ Whether the result of intentional or unintended processes, the Court's equal protection case law reflects this indefensible belief that antiwhite oppression exists in the United States.

Although the Court's equal protection doctrine offers little hope to vulnerable social groups, some plaintiffs have successfully asserted dignity-based claims to challenge harmful state action. Despite the possible positive outcomes in these cases, legal scholars must critically examine the relative strengths and weaknesses of dignity doctrines versus a robust equal protection analysis. As the next Part of this Article demonstrates, dignity-based claims cannot provide the same level of redress to vulnerable groups as an equal protection doctrine that seeks to mitigate rather than facilitate racial hierarchy.

\section{TOWARDS A “NEWER” Equal PROTECTION That PROTECTS SUBORDINATE CLASSES}

This Part argues for the development of a newer equal protection. In light of the informative empirical research conducted by social psychologists, this equal protection doctrine would accommodate group identity and rights. It would not conflate race consciousness with racism or argue that the former causes social unrest. The revised equal protection doctrine this Article advocates would recognize the ongoing significance of racism and its impact upon persons of color. This equal protection analysis would not treat whites as a racially subordinate class-a finding that lacks an empirical basis. Finally, the doctrine developed in this Part would not enforce the perspectives of whites as a class over those of persons of color, or of any dominant class over subordinate groups. In other words, this newer equal protection doctrine would not facilitate group domination, as does the Court's current case law.

\section{A. Groups, Difference, and Society}

The Court asserts that its reluctance to recognize group-based inequality stems from its fear of balkanization. Yoshino's groundbreaking work on this subject contends that the Court and society suffer from "pluralism anxiety."269 Assuming Yoshino's diagnosis is correct, fear of balkanization does not justify the Court's retreat from group-based equal protection.

\footnotetext{
${ }^{268}$ Norton \& Sommers, supra note 209, at 216.

269 See Yoshino, The New Equal Protection, supra note 5.
} 


\section{Healthy Responses to Anxiety}

Anxiety has two meanings. The first meaning is used in conversational English, while the second meaning has a clinical dimension. Both the clinical and nonclinical uses of the word "anxiety" derive from and connote physical and emotional pain related to some generalized or amorphous threat. ${ }^{270}$ Psychiatrists Juan J. López-Ibor and María-Inés López-Ibor have written quite an extensive article discussing the etymology and present-day meaning of anxiety. ${ }^{271}$ They chart the evolution of the term through Greek, Latin, French, and English employing numerous historical sources. ${ }^{272}$ After a substantial analysis, they conclude that:

The word anxiety and those that share the same Latin and Greek etymology describe feelings characterized by deep suffering experienced as being at risk by a notyet-identified threat. The emotion is linked to sensations of choking, oppression in the chest, lack of breath which allow us to differentiate anxiety from anguish, and the sensation of being inhibited (as in anguish) from that of being uneasy or nervous (as in anxiety). Anxiety is not only a clinical symptom of many psychiatric disturbances, but also a radical experience of human beings as substantiated by phenomenological and existentialist schools of thought, which consider that anguish is the experience of being thrown into the world. ${ }^{273}$

Medical professionals typically recommend psychological therapy to control the irrational and panicked reaction to ordinary stimuli. ${ }^{274}$ In extreme cases, pharmacological intervention combined with therapy offers promise. ${ }^{275}$ Medical studies, however, report that cognitive avoidance, or efforts to escape anxiety by ignoring the stressor, can actually make conditions worse. People who utilize cognitive avoidance simply add on a new layer of anxiety: they now worry about avoiding the stressor in ad-

270 See generally Juan J. López-Ibor \& María-Inés López-Ibor, Anxiety and Logos: Toward a Linguistic Analysis of the Origins of Human Thinking, $120 \mathrm{~J}$. AFFECTIVE DisORDERS 1 (2010) (discussing etymology of anxiety).

${ }^{271} \mathrm{Id}$.

${ }^{272} I d$.

${ }^{273}$ Id. at 10.

274 Richard G. Heimberg, Cognitive-Behavioral Therapy for Social Anxiety Disorder: Current Status and Future Directions, 51 SoC'y BIOLOGICAL PSYCHIATRY 101 (2002) (discussing effectiveness of cognitive behavioral therapy for patients with social anxiety disorder).

${ }^{275}$ Herman G. M. Westenberg \& Michael R. Liebowitz, Overview of Panic and Social Anxiety Disorders, 65 J. CliniCAL PSYCHIATRY (Supp. 14) 22, 24 (2004) (concluding that combination therapy and medication might help treat prolonged cases of social anxiety disorder). 
dition to experiencing the same anxiety that triggered their avoidance strategies. ${ }^{276}$ If Yoshino's anxiety trope is accurate, the Court's and society's efforts to avoid racial and ethnic pluralism actually may cause more serious harm than accepting the multicultural reality of the United States.

Although this discussion of clinical anxiety is intended as a metaphor - just as Yoshino's use of the term-contemporary equal protection doctrine, like cognitive avoidance strategies, does not confront actual societal conditions. Instead, the Court has created a doctrine that rests on a fictitious portrayal of the United States as a society in which whites are racially oppressed; multiculturalism is corrosive; group-rights have no constitutional foundation; and race-based remedies impose the same degree of harm as Jim Crow and slavery. This doctrine does not come close to providing equal justice. The Court must try a different approach.

A fair equal protection doctrine would rest on empirical research, rather than disproven assertions regarding the status of United States race relations. The Court should reform equal protection to recognize the benefits of multiculturalism and harms of colorblindness; inevitability of a group-based social structure; persistence of racism against persons of color; and the privileges whites possess in a racially hierarchical society.

\section{Multiculturalism Helps Society; Colorblindness Harms Society}

Although the Court fears balkanization, empirical research demonstrates that ethnic and racial diversity improves social institutions and helps to generate mutual understanding and tolerance across social groups. Some social capital literature, which some scholars and advocates have used to justify the demise of group-based equal protection, actually finds that multiculturalism generates many social benefits. ${ }^{277}$ To the extent that some scholars contend that multiculturalism causes intergroup tension, a much larger number of scholars have refuted this assertion or found that other factors like racial and class inequality more strongly correlate with or cause intergroup tension. ${ }^{278}$ Controlling for these other factors, multiculturalism has very little negative impact upon social cohesion. ${ }^{279}$

Social psychologists have conducted studies that find that whites have a more favorable view of out-groups when they embrace multiculturalism. ${ }^{280}$ By contrast, colorblindness helps to justify the existing une-

276 Stefan G. Hofmann, Cognitive Factors that Maintain Social Anxiety Disorder: A Comprehensive Model and its Treatment Implications, 36 COGNITIVE BeHAV. THERAPY 193, 204 (2007) (finding that a coping strategy that avoids source of anxiety actually exacerbates the symptoms of the disorder).

277 See supra text accompanying notes 152-66.

278 See supra text accompanying notes 152-69.

279 See supra text accompanying notes 152-54, 165-66.

${ }^{280}$ See Christopher Wolsko, Bernadette Park, Charles M. Judd \& Bernd Wittenbrink, Framing Interethnic Ideology: Effects of Multicultural and Color- 
qual distribution of vital resources. ${ }^{281}$ Colorblindness operates as a legitimizing myth that defends social dominance and as a form of system justification that convinces individuals that the United States is a just society-in spite of deep racial inequality. ${ }^{282}$

Colorblindness can also make people blind to racism. Researchers conducted a study that exposed two groups of students to a "multimedia" storybook. ${ }^{283}$ The book-which consisted of a series of images displayed on computers with a narrator-described a third-grade student's effort to arrange a class performance to support racial equality. ${ }^{284}$ The two groups of students heard the same story, except that the scripts diverged in one critical respect. One group of students received a lecture regarding the virtues of colorblindness. ${ }^{285}$ The other group of children listened to a lecture that promoted the recognition and appreciation of ethnic and racial diversity. ${ }^{286}$ A teacher, unaware of the study, then read three scenarios to all of the students. These three scenarios involved student interactions that were nonracist, ambiguously racist, and explicitly racist. ${ }^{287}$ The explicitly racist story involved an incident of racist bullying during a soccer game. ${ }^{288}$ Researchers asked the students to describe the events they heard and to state whether any of the three scenarios involved acts of racial discrimination. The students' responses confirm the hypothesis that the promotion of colorblindness can lead to racism-blindness. ${ }^{289}$

Blind Perspectives on Judgments of Groups and Individuals, 78 J. PERSONALITY \& SOC. PSYCHOL. 635, 648-49 (2000) (finding that multiculturalism causes a more positive perception of out-groups among whites).

${ }^{281}$ See Kimberly Rios Morrison, Victoria C. Plaut \& Oscar Ybarra, Predicting Whether Multiculturalism Positively or Negatively Influences White Americans' Intergroup Attitudes: The Role of Ethnic Identification, 36 PERSONALITY \& SOC. PSYCHOL. BulL. 1648, 1658 (2010) ("Furthermore, colorblind ideologies may reinforce the status quo by legitimating existing inequalities between White Americans and racial and ethnic minorities.”) (citations omitted).

282 See supra text accompanying notes 204-07.

${ }^{283}$ Evan P. Apfelbaum, Kristin Pauker, Samuel R. Sommers \& Nalini Ambady, In Blind Pursuit of Racial Equality?, 21 PSYCHOL. SCI. 1587 (2010).

284 See id.

${ }^{285}$ Id. at 1588 (The color-blind version called for minimizing race based distinctions and considerations (e.g., "That means that we need to focus on how we are similar to our neighbors rather than how we are different," "We want to show everyone that race is not important and that we're all the same”)).

${ }^{286} \mathrm{Id}$. ("The value diversity version endorsed recognition of these same differences (e.g., "That means we need to recognize how we are different from our neighbors and appreciate those differences," "We want to show everyone that race is important because our racial differences make each of us special”)).

${ }^{287}$ Id. at $1588-89$.

${ }^{288} \mathrm{Id}$. at 1589 (describing racist scenario involving a white student tripping a black student because he "knew he could tell that [the victim] played rough because he is Black”).

289 See generally id. 
With respect to the multiculturalism group, seventy-seven percent of the students perceived racism in the explicitly racist category; forty-three percent perceived racism in the ambiguously racist category; and zero percent perceived racism in the control category. On the other hand, students who were primed for colorblindness tended not to report any racist incidents. Only fifty percent of the colorblind group perceived racism in the explicitly racist category; ten percent perceived racism in the ambiguously racist category; and zero percent perceived racism in the control category. The students' reactions were videotaped. ${ }^{290}$

The researchers then asked teachers who were unaware of the study to view the students' videotaped responses to the incidents and then indicate whether the behavior the children described warranted intervention by a teacher. The researchers found that the teachers were less likely to believe that descriptions of ambiguously and explicitly racist scenarios described by the colorblind group warranted teacher intervention. ${ }^{291}$ Thus, not only were the students less likely to perceive racist incidents if they were previously exposed to colorblindness as a value, they were also less likely to describe the behavior they viewed to their teachers in a manner that would provoke intervention. ${ }^{292}$

Although multiculturalism generates many social benefits, it also involves risks. Studies show that whites do not see themselves as participants in racial and ethnic diversity. ${ }^{293}$ This could result from a tendency of whites not to see themselves consciously as a racial group or due to the way some people frame multiculturalism. ${ }^{294}$ This risk is not insurmountable. Ethnic and racial diversity policies need not preclude whites. Nonetheless, to the extent that diversity seeks to remedy past discrimination on the basis of race, then de-emphasizing whites is rational, not invidious. ${ }^{295}$

In addition, intergroup tension is not inherently bad, as the Court and some scholars suggest. Rather, intergroup racial tension might occur because suppressed minority viewpoints are finally receiving attention

${ }^{290}$ Id. at 1589.

${ }^{291}$ Id. at 1590.

${ }^{292} \mathrm{Id}$.

293 See supra text accompanying note 198.

294 See Barbara J. Flagg, "Was Blind, But Now I See”: White Race Consciousness and the Requirement of Discriminatory Intent, 91 MICH. L. REV. 953, 957 (1993) ("The most striking characteristic of whites' consciousness of whiteness is that most of the time we don't have any.”); see also supra text accompanying note 198 (discussing whites' fear of exclusion from multiculturalism policy).

295 John R. Dovidio, Tamar Saguy \& Nurit Shnabel, Cooperation and Conflict within Groups: Bridging Intragroup and Intergroup Processes, 65 J. SoC. IssuES 429, 440 (2009) ("Discussing power inequalities can implicate the responsibility that the advantaged group has in creating injustice thus admitting its 'moral debt' toward the disadvantaged group."). 
from the majority. ${ }^{296}$ Silencing minority views for the sake of avoiding tension is a self-defeating goal. Forcing racial minorities to embrace colorblindness, especially within a context of racial inequality, causes resentment, withdrawal, and other harms. ${ }^{297}$ When equality and diversity occur, however, organizations and societies can operate more robustly and innovatively. ${ }^{298}$

\section{Group-Based Societies and Rights}

Social scientists have found that all societies have historically involved group-based hierarchy. ${ }^{299}$ Also, individuals do not exist outside of the sociocultural space in which they live. ${ }^{300}$ Despite the fundamental relevance of groups to society, the Court sees collective identity and

${ }^{296}$ Id. at 435 (discussing the risk of tension and conflict from clashing perspectives of dominant and subordinate groups but arguing that tolerating this tension could "create a reservoir of distinct resources and perspectives upon which the society may draw in times of need"); id. at 436 (arguing that "conflict can be a process that recognizes dissent, allows the expression of minority views and increases the diversity of ideas and perspectives available within the group”); Lisa Troyer \& Reef Youngreen, Conflict and Creativity in Groups, 65 J. SOC. Issues 409, 412-13 (2009) (discussing the benefits of dissent within organizations).

${ }^{297}$ Dovidio et al., supra note 292, at 440 (focusing on "commonalities, mutual acceptance and empathy . . . will satisfy only the needs of the advantaged group and fail to address the disadvantaged group's need for recognition and empowerment”); Deborah Son Holoien \& J. Nicole Shelton, You Deplete Me: The Cognitive Costs of Colorblindness on Ethnic Minorities, $48 \mathrm{~J}$. EXPERIMENTAL SOC. PSYCHOL. 562, 564 (2012) (“Although colorblindness and multiculturalism are two different avenues to attaining intergroup harmony, our findings suggest that in short-term interracial interactions, colorblindness may hurt ethnic minorities' cognitive functioning”); Victoria C. Plaut, Kecia M. Thomas, \& Matt J. Goren, Is Multiculturalism or Color Blindness Better for Minorities?, 20 PsYCHOL. SCI. 444, 445 (2009) (“Our results suggest that dominant-group members' diversity beliefs (e.g., multiculturalism and color blindness) have palpable implications for minority colleagues' psychological engagement. Paradoxically, emphasizing minimization of group differences reinforces majority dominance and minority marginalization.”); Valerie PurdieVaughns, Claude M. Steele, Paul G. Davies, Ruth Ditlmann, \& Jennifer Randall Crosby, Social Identity Contingencies: How Diversity Cues Signal Threat or Safety for African Americans in Mainstream Institutions, 94 J. PERSONALITY \& SOC. PSYCHOL. 615 (2008) (finding lowest levels of trust and highest levels of perceived identity threat among African Americans in environments with low minority representation coupled colorblind ideology).

${ }^{298}$ See Troyer \& Youngreen, supra note 296 (discussing benefits of dissent in workplace); Plaut et al., supra note 297, at 445 (discussing negative workplace effects of colorblindness upon persons of color).

${ }^{299}$ See SidANIUS \& PRATTO, supra note 186, at 31.

${ }^{300}$ See supra text accompanying notes $182-83$. 
rights as dangerous and inconsistent with American constitutional tradition. ${ }^{301}$ Both of these contentions are deeply problematic.

A substantial amount of social science data demonstrates that, standing alone, groups do not harm society. Instead, nonrecognition of groups and the existence of group-based inequality diminish social cohesion. On the other hand, multiculturalism and the amelioration of social and economic inequality improve social and institutional relations. ${ }^{302}$

Furthermore, while American culture certainly promotes the idea of individualism over groups, this cultural tradition falls apart under closer scrutiny for at least two reasons. First, whites are more likely to accept individualism over group identity than are people of color. ${ }^{303}$ So, this tradition is not exactly "American" when the perspectives of people of color are taken into consideration. Second, research suggests a more complicated relationship between the things whites value in their own lives and their perception of what most whites want. In one study, for example, a group of white participants ranked the values they deemed important from their own perspective and the values that they thought were important for most white Americans. ${ }^{304}$ The results showed that on an individual basis whites valued "personal virtues and interpersonal relationships," but they "characterized White Americans as placing value on the cultivation of more specific personal skills ... and on the acquisition of material rewards."305

In addition, while the Court views group-based identities as dangerous and balkanizing, social scientists have also demonstrated the essential connection between the individual and society. The self is a social construct, formed out of interactions and responses to the broader society. ${ }^{306}$ The Court, however, treats the two categories as mutually exclusive.

Moreover, despite contrary language in some cases, the Court has never applied a wholesale rule against the recognition of group rights. It is true that the political theorists who inspired the framers of the Constitution heralded individual liberty, but individual liberty and group rights are not inevitably inconsistent. ${ }^{307}$ For example, the Equal Protection

301 See supra text accompanying notes 230-32.

302 See supra text accompanying notes 276-98.

303 See supra text accompanying notes 202-04.

${ }^{304}$ Wolsko et al., supra note 280, at 638.

${ }^{305} \mathrm{Id}$. at 641(noting that "This pattern of rankings suggests that, at least to some degree, our White participants may not strongly identify with what they perceive as 'White Americans in general'”).

306 See supra text accompanying notes 182-85.

${ }^{307}$ Some research, for example, finds serious contradictions in Locke's individualism. For instance, his assumption that propertied white men would control the state and enforce property rights implies a communitarian supremacy over the individual-especially those individuals whom he did not recognize as having full agency. See C.B. MacPherson, The Social Bearing of Lock's Political Theory, 7 W. POL. Q. 1 (1954). 
[Vol. 22:1

Clause protects individuals from racial discrimination, but the Court applies strict scrutiny to racial classifications due to the history of racial subordination — not because certain individuals during American history experienced racial discrimination. ${ }^{308}$ Racial discrimination, as the Court has acknowledged, is dangerous due to the widespread oppression it caused. ${ }^{309}$ Modern equal protection doctrine evolved, in part, due to the Court's desire to protect "discrete and insular minorities." ${ }^{310}$ Also, the Court (and Congress) has specifically recognized group rights in many legal settings. ${ }^{311}$ In addition, the Court has frequently limited the rights

${ }^{308}$ See Jenny Rivera, An Equal Protection Standard for National Origin Subclassifications: The Context That Matters, 82 WASH. L. REV. 897, 908 (2007) ("Notwithstanding the Supreme Court's apparent individual rights approach to equal protection, group affiliation based on race has been a vital concern in equal protection analysis. Society, government institutions, and the courts have historically considered association with a particular group-both an individual's voluntary association and association based on societal perception - as fundamental to the individual and the treatment accorded to the individual in terms of equal protection.”).

${ }^{309}$ See supra text accompanying note 79.

${ }^{310}$ See Taunya Lovell Banks, What Is a Community? Group Rights and the Constitution: The Special Case of African Americans, 1 MARGINS 51, 54 (2001) ("Justice Stone in United States v. Carolene Products expressed the once commonly held belief that the Supreme Court can exercise judicial review to protect the rights of 'discrete and insular' minority groups from the tyranny of the majority.”).

${ }^{311}$ Id. at 53-54 ("Following western liberal tradition, constitutional rights in the United States are framed as individual rather than group rights. Courts, however, routinely recognized group rights. Corporate entities, which are voluntary communities of shareholders, have rights. Similarly, trade unions, which are voluntary communities of workers, have group-based rights to negotiate with employers on behalf of their members. Likewise, religious and charitable associations have group-based rights. So do Native American communities like the Hopi, Navajos, and Cherokees, who are formally recognized by the federal government and are treated as domestic sovereign entities. Even activist civil rights organizations have group rights. So, perhaps it is misleading to say that American law only protects individual rights.”); Ronald R. Garet, Communality and Existence: The Rights of Groups, 56 S. CAL. L. REV. 1001, 1006 (1984) ("Groups receive extensive protection under contemporary constitutional law. For example, groups appear to have a right, under the privacy, speech, and association norms of the first and fourth amendments, to refuse to divulge membership lists. Groups also have a right under the free exercise clause of the first amendment to obtain exemptions from regulations that impose unnecessary burdens on group religiosity. Moreover, groups have a right under the thirteenth and fourteenth amendments to be free from discrimination or stigmatization by the state. Perhaps groups have a right under basic federalist principles to enforce 'community standards,' or to regulate activities which are so obscene or indecent as to outrage community norms of decency.”). 
of individuals in order to accomplish broader societal goals. ${ }^{312}$ Accordingly, Court precedent does not support the idea that group rights have no place in American constitutionalism. Furthermore, the spread of group rights within human rights law and in foreign constitutions provides an additional basis for the Court to rethink its analysis of group rights in the equal protection context. ${ }^{313}$

\section{Racism Is Still Relevant}

Whites tend to view racism as insignificant. ${ }^{314}$ People of color, on the other hand, are more likely to believe it remains a substantial barrier to equal opportunity. ${ }^{315}$ By every statistical barometer of well-being, race impedes social and economic betterment. ${ }^{316}$ Individual and institutional acts of racism continue; also, the present-day effects of unremedied past discrimination continue to plague communities of color. ${ }^{317}$

These observations do not negate the relevance of other social categories such as sex, sexual orientation, or poverty. These findings also do

${ }^{312}$ See T. Alexander Aleinikoff, Constitutional Law in the Age of Balancing, 96 YALE L.J. 943 (1987) (discussing Court doctrine that balances rights against the pursuit of governmental policy interests); Jud Mathews \& Alec Stone Sweet, All Things in Proportion? American Rights Review and the Problem of Balancing, 60 EMORY L.J. 797, 813-86 (2011) (discussing balancing of rights and policy in U.S. adjudication).

${ }^{313}$ Graham v. Florida, 560 U.S. 48, 81 (2011) (justifying decision to invalidate "life without parole sentences on juvenile nonhomicide offenders," in part, because "the United States is the only Nation" that permits such sentences and because "Article 37(a) of the United Nations Convention on the Rights of the Child," which the United States has not ratified, bans such sentences); Roper v. Simmons, 543 U.S. 551, 575 (2005) (“Our determination that the death penalty is disproportionate punishment for offenders under 18 finds confirmation in the stark reality that the United States is the only country in the world that continues to give official sanction to the juvenile death penalty."); Lawrence v. Texas, 539 U.S. 558, 573 (2003) (citing, in part, to foreign law in order to find an "emerging" tradition protecting sexual privacy); see also Thompson v. Oklahoma, 487 U.S. 815, 830-31 (1988) ("Although the death penalty has not been entirely abolished in the United Kingdom or New Zealand (it has been abolished in Australia, except in the State of New South Wales, where it is available for treason and piracy), in neither of those countries may a juvenile be executed. The death penalty has been abolished in West Germany, France, Portugal, The Netherlands, and all of the Scandinavian countries, and is available only for exceptional crimes such as treason in Canada, Italy, Spain, and Switzerland. Juvenile executions are also prohibited in the Soviet Union.”); Banks, supra note 310, at 6872 (discussing rise of group protection by human rights charters and foreign courts, but questioning whether the United States would agree to such an approach).

${ }^{314}$ See supra text accompanying notes 203-05.

${ }^{315} \mathrm{Id}$.

${ }^{316}$ See supra text accompanying note 205.

${ }^{317}$ Markus et al., supra note 184, at 243-49. 
[Vol. 22:1

not imply that every negative event in the lives of persons of color stems from racism. Instead, these findings mean that equal opportunity remains elusive for many Americans due to race. To the extent that the Equal Protection Clause was intended to ameliorate racial oppression, the Court's doctrine does not facilitate the achievement of that goal. Even if original intent is irrelevant, the Court has not even tried to justify its privileging of white beliefs about race-even those that are patently incorrect from an empirical standpoint - over the values held by subordinate groups.

\section{Whites Are Not Racially Oppressed}

Although recent studies suggest that whites think that they are a vulnerable racial class, this belief is not true. The same statistics that demonstrate the subordinate position of persons of color document the privilege of whites. ${ }^{318}$ Immunity from the debilitating impact of racism is a powerful social advantage. Possession of the intergenerational benefits of racial privilege is also a tremendous asset that advances the economic, political, and social status of whites. ${ }^{319}$

This analysis does not mean that whites never experience racial or other forms of mistreatment. Nor does it mean that any state action that singles out whites is justifiable. This analysis does, however, imply that the Court should give private and state actors more latitude to treat whites and persons of color differently, within reasonable constraints, in order to remedy pervasive and substantial racial inequality. Whites and persons of color are not similarly situated with respect to the distribution of social resources. Racism caused this extreme imbalance. Recognizing race in order to remedy racial injustice does not constitute racism. That logic would, by analogy, call into question a policy that freed slaves on the grounds that doing so would discriminate against people who are not slaves. The reverse-discrimination legitimizing myth began in the midnineteenth century when Congress began to pass laws to ameliorate the conditions of racial inequality and slavery. ${ }^{320}$ It continues to frame argu-

${ }^{318}$ Stephanie M. Wildman \& Adrienne D. Davis, Language and Silence: Making Systems of Privilege Visible, 35 SANTA ClaRA L. REV. 881, 895 (1995) ("Anti-discrimination advocates focus only on one portion of the power system, the subordinated characteristic, rather than seeing the essential links between domination, subordination, and the resulting privilege.”).

${ }^{319}$ See Ira Katznelson, WHEN AfFIRMATIVE ACTION WAS WHITE: AN UnTOLD HistoRY of RACIAL INEQUALITY IN TWENTIETH-CENTURY AMERICA (2005) (discussing the various twentieth century policies that created white wealth); Melvin Oliver and Thomas M. Shapiro, BlACK WEALTH/WHITE WEALTH: A NEW PERSPECTIVE ON RACIAL INEQUALITY (2nd ed. 2006) (discussing racial disparities related to intergenerational transfer of wealth).

${ }^{320}$ See supra text accompanying notes $213-14$. 
ments in opposition to racial justice, and it serves as a justification for the perpetuation of racial inequality. ${ }^{321}$

\section{B. Towards an Equal Protection Doctrine That Actually Protects}

This section argues that the Court should not enable the anxieties that whites or individual justices have regarding balkanization. Barring a very catastrophic event, the United States will remain ethnically and racially diverse. An equality doctrine that discounts diversity, groups, and equality does not reflect the sociocultural landscape of the country. Moreover, this doctrine increases inequality and tension-the exact opposite outcome of the Court's stated purpose. ${ }^{322}$ The most effective equal protection doctrine for contesting group dominance is antisubordination theory.

\section{What Is Antisubordination Theory?}

Many legal scholars have urged the Court to reform equal protection doctrine by applying antisubordination theory. ${ }^{323}$ According to antisubordination theory, the Equal Protection Clause prohibits the "subjugation or the formation of a caste structure." 324 Antisubordination theory seeks to eliminate state action that "imposes or reinforces the social and economic vulnerability of classes of persons.”325

${ }^{321}$ See supra text accompanying notes 215-17.

322 See supra text accompanying notes 276-98.

323 See Laurence H. Tribe, American Constitutional LaW §16-21, at 1515 (2d ed. 1988); Ruth Colker, Anti-Subordination Above All: Sex, Race, and Equal Protection, 61 N.Y.U. L. REV. 1003 (1986); Dorothy E. Roberts, Punishing Drug Addicts Who Have Babies: Women of Color, Equality, and the Right of Privacy, 104 HARV. L. REV. 1419, 1454 (1991); Reva Siegel, Equality Talk: Antisubordination and Anticlassification Values in Constitutional Struggles Over Brown, 117 HaRv. L. REV. 1470 (2004); Cass Sunstein, The Anticaste Principle, 92 Mich. L. REV. 2410 (1994). See also Hutchinson, Inversion of Privilege and Subordination, supra note 3, at 682-98.

${ }^{324}$ Cass Sunstein makes this point in his groundbreaking article on the subject of caste and equal protection:

[T] he anticaste principle forbids social and legal practices from translating highly visible and morally irrelevant differences into systemic social disadvantage, unless there is a very good reason for society to do so. On this view, a special problem of inequality arises when members of a group suffer from a range of disadvantages because of a group-based characteristic that is both visible for all to see and irrelevant from a moral point of view. This form of inequality is likely to be unusually persistent and to extend into multiple social spheres, indeed into the interstices of everyday life.

See Sunstein, supra, note 323, at 2411-12.

${ }^{325}$ Hutchinson, Not Without Political Power, supra note 70. 
Because antisubordination theory addresses concrete manifestations of deprivation, it would not invalidate policies simply because they take race into account. Instead, antisubordination theory would also permit state action taken to ameliorate the conditions of inequality, even if it categorized people by race. Also, rather than following the antidifferentiation approach that the Court currently utilizes, antisubordination theory would treat as impermissible or at least suspicious any state action, intentional or otherwise, that compels vulnerable social groups to live "perpetually in social and economic deprivation"-even if those policies were facially neutral with respect to race. ${ }^{326}$

Furthermore, as many other scholars have observed, antisubordination theory has tremendous support in constitutional history and tradition. The Fourteenth Amendment was ratified to invalidate the Black Codes, which the Southern states enacted to restore racially based slavery. ${ }^{327}$ The Black Codes were not infamous simply because they mentioned race; instead, these laws offended notions of fairness because they sought to nullify the Thirteenth Amendment and reenact slavery. ${ }^{328}$ The Court's first opinion that construed the meaning of the Reconstruction Amendments recognized the antisubordination purpose of these enactments. In The Slaughter-House Cases, the Court found that "the pervading purpose" of the Reconstruction Amendments was the "freedom of the slave race, the security and firm establishment of that freedom, and the protection of the newly-made freeman and citizen from the oppressions of those who had formerly exercised unlimited dominion over him." 329 Today, however, the Court construes the Fourteenth Amendment as a tool for enforcing white opinions regarding the status of race relations and the appropriateness of race-based remedies. Antisubordination theory would reject the privileging of dominant social groups.

\section{A Few Thoughts About Dignity}

Although dignity-based arguments should not supplant equal protection, these arguments are not inherently harmful to social justice. Instead, as proponents of dignity claims have argued, this particular approach has helped vulnerable classes, particularly LGBT individuals, secure legal victories.

${ }^{326} I d$.

${ }^{327}$ Id.

${ }^{328} \mathrm{Id}$.

${ }^{329}$ Slaughter-House Cases, 83 U.S. 36, 71 (1872); see also Strauder v. West Virginia, 100 U.S. 303, 308 (1879) (Reconstruction Amendments give blacks right against discriminatory and "unfriendly" laws and from state action "implying inferiority in civil society, lessening the security of their enjoyment of the rights which others enjoy, and discriminations which are steps towards reducing them to the condition of a subject race”); Loving v. Virginia, 388 U.S. 1, 11-12 (1967) (finding that anti-miscegenation law promotes "White Supremacy" which violates the Fourteenth Amendment). 
That dignity claims have the possibility of producing successful outcomes for vulnerable classes does not mean that they should replace equal protection. Group dominance stems from the unequal possession of political power and resources. Dignity arguments that rest on liberty do not require eradication of these distinctions. Instead, in its current form, the dignity doctrine attends to the emotional or stigmatic effects of state action. These same concerns, however, have led to the judicial invalidation of numerous policies that were implemented to ameliorate the conditions of racial inequality. ${ }^{330}$

Additionally, dignity arguments do not focus on power disparity among social groups. In fact, legal scholars have praised dignity-based claims because they make the dynamics of social group relationships irrelevant. ${ }^{331}$ It is impossible to remedy the harms of racial inequality, however, without considering group-based inequality. Some racial injuries resemble stigmatic harms. ${ }^{332}$ Many others, however, relate to material deprivation. ${ }^{333}$ Because dignity doctrines do not provide redress for substantive inequality, they cannot replace a robust antisubordination analysis. ${ }^{334}$ Indeed, several dignity cases already reveal the limits of this doctrine for vulnerable social groups. ${ }^{335}$ Litigants should certainly use available doctrines that can help them achieve litigation victories. These victories, however, should not determine how legal scholars and courts interpret equal protection, especially if the resulting interpretation sustains group domination.

330 See Markus et al., supra note 184, at 243-49.

331 See Yoshino, The New Equal Protection, supra note 5, at 776 ("The Court seems to understand pluralism as a challenge to a progressive agenda. At the same time, it has seen that challenge as one that can be overcome by using liberty analysis, which draws on a broader, more inclusive form of 'we.”').

${ }^{332}$ Brown v. Bd. of Educ., 347 U.S. 483, 494 (1954) ("Such considerations apply with added force to children in grade and high schools. To separate them from others of similar age and qualifications solely because of their race generates a feeling of inferiority as to their status in the community that may affect their hearts and minds in a way unlikely ever to be undone.”).

333 See Markus et al., supra note 184, at 243-49.

${ }^{334}$ Even if dignity doctrines addressed economic needs, this would inevitably raise questions of equality. For example, states might exclude some groups from the substantive right or provide less to other groups. Because group-based inequality will remain a structural aspect of American society, legal equality concerns will necessarily arise.

335 See Shelby County v. Holder, 133 S. Ct. 2612 (2013) (placing dignity of Southern states above black and Latino voters); Gonzales v. Carhart, 550 U.S. 124 (2007) (placing dignity of medical profession above rights of women to an abortion); Parents Involved in Cmty. Sch. v. Seattle Sch. Dist. No. 1, 551 U.S. 701 (2007) (placing dignity of individual white students against the interest of students of color not to attend racially isolated schools); Planned Parenthood of Southeastern Pennsylvania v. Casey, 505 U.S. 833 (1992) (failing to find an undue burden for class of poor women, but finding one for married women). 


\section{CONCLUSION}

Neurological studies suggest that people detect skin color very rapidly, in 120 milliseconds, or less than $1 / 7$ of a second. ${ }^{336}$ Prevailing equal protection doctrine, however, rests on the fiction that people can become blind to race. The history of racial oppression should make the Court sensitive to social policies that categorize individuals according to race. This same history, however, should also lead the Court to adopt a critical stance towards policies that justify the systemic inequality of the same classes of people who, due to historical and contemporary discrimination, occupy the bottom end of America's racially hierarchical society. Instead, the Court has taken the opposite approach. The Court has transformed the Equal Protection Clause into a formidable barrier to social policies that seek to remedy racial oppression. At the same time, the Court construes the Equal Protection Clause as generally permitting policies that cause significant harm to racially oppressed individuals-so long as those policies do not mention race explicitly. Furthermore, the Court has expressed a willingness to depart from its deferential stance towards policies that disparately affect racial classes when these practices harm whites. The Court has also explained that it must apply strict scrutiny to policies implemented to ameliorate the conditions of racial subordination in order to make sure they do not harm innocent whites. Taken together, the Court's differential stances towards remedial uses of race and facially neutral but racially injurious policies help to facilitate, by design or effect, racial dominance in the United States.

The Court's equal protection doctrine also implements core beliefs about race relations that whites hold, while it rejects the positions taken by most persons of color. The Court prefers colorblindness to multiculturalism as a method of preserving social cohesion; rejects group identity and favors individualism for social organization; treats racism as a relic of prior generations; and perceives whites as racial victims. Enforcement of these beliefs-which an abundance of social science data refutes or undermines-legitimizes present-day conditions of racial inequality. Furthermore, while the Court contends that its rejection of group-based equality claims will boost social cohesion, empirical research shows that it has the opposite effect. Colorblindness and individualism combined with racial and class inequality exacerbate social divisions.

Because equal protection doctrine currently offers very little hope to vulnerable classes, some scholars have looked for alternatives. The Court's recent openness to using dignity-based claims to extend protection to vulnerable groups has led some scholars to promote the Due Process Clause as a substitute for equal protection. Although switching to dignity might generate litigation victories, this doctrinal setting cannot

336 Tiffany A. Ito \& Geoffrey R. Urland, Race and Gender on the Brain: Electrocortical Measures of Attention to the Race and Gender of Multiply Categorizable Individuals, 85 J. PERSONALITY \& SOC. PSYCHOL. 616, 621 (2003). 
provide comprehensive relief for the variety of harms that racism causes. These harms include material as well as stigmatic injuries. The Court's dignity doctrine, however, only targets stigmatic and procedural harms; it does not seek to diminish group-based material deprivation. In fact, some scholars favor dignity arguments precisely because they do not require examination of group-based dynamics.

Furthermore, the Court has utilized dignity arguments to invalidate remedial usages of race. It has ruled that state and federal policies designed to prevent and remedy racial subordination offend the dignity of whites and state governments, assigning to states a human-like quality. When confronted with a choice of promoting racial egalitarianism over inequality, the Court chose the latter.

Application of antisubordination equality theories can help refashion Court doctrine so that it provides actual protection to vulnerable groups. Antisubordination theories, however, will continue to face resistance from an ideologically polarized Court with a majority of justices who strongly support current approaches to equal protection. Evolution in Court doctrine will require the same forces that have led to legal changes historically, including social movement activism, election politics, public opinion, and cues from the political branches. Legal academics should contribute to this process by highlighting the role that the Court plays in preserving inequality and by continuing to craft theories that can inform equality doctrine in a more favorable judicial climate. 
